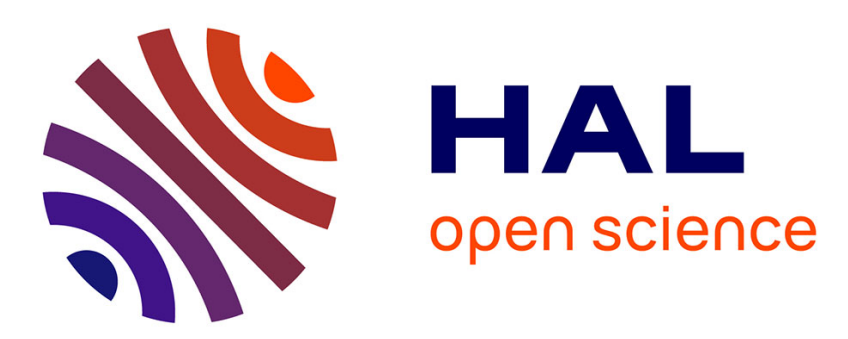

\title{
An Exploratory Study of Creativity, Personality and Schooling Achievement
}

Noémi Berlin, Jean-Louis Tavani, Maud Beasançon

\section{To cite this version:}

Noémi Berlin, Jean-Louis Tavani, Maud Beasançon. An Exploratory Study of Creativity, Personality and Schooling Achievement. 2015. hal-01227497

\author{
HAL Id: hal-01227497 \\ https://hal.science/hal-01227497 \\ Preprint submitted on 11 Nov 2015
}

HAL is a multi-disciplinary open access archive for the deposit and dissemination of scientific research documents, whether they are published or not. The documents may come from teaching and research institutions in France or abroad, or from public or private research centers.
L'archive ouverte pluridisciplinaire HAL, est destinée au dépôt et à la diffusion de documents scientifiques de niveau recherche, publiés ou non, émanant des établissements d'enseignement et de recherche français ou étrangers, des laboratoires publics ou privés. 


\title{
An Exploratory Study of Creativity, Personality and Schooling Achievement*
}

\author{
Noémi Berlinł Jean-Louis Tavani; Maud Beasançon ${ }^{\S}$
}

October 2015

\begin{abstract}
In this paper, we investigate the link between schooling achievement and creativity scores, controlling for personality traits and other individual characteristics. Our study is based on field data collected in a secondary school situated in a Parisian suburb. Four scores of creativity were measured on 9th graders. Schooling achievement was measured by the test scores obtained by pupils in different subjects. We find that verbal divergent thinking, which is a subtype of creativity, negatively predicts the grades in most subjects, but that graphical integrative thinking is positively correlated with scientific grades. There is no significant correlation with the other measures of creativity, implying a low importance of creativity in school. In line with previous work, we find that conscientiousness and openness are positively associated with grades. Girls have higher grades than boys but do not have a higher probability of passing a national exam.
\end{abstract}

Keywords: Schooling achievement, creativity, personality traits, field data.

${ }^{*}$ This work was supported by the French Research National Agency (ANR) under Grant number ANR-10-CREA-008. We are grateful to José de Valverde and the secondary public school "SaintExupéry" of Rosny-Sous-Bois, France. We would also like to thank the anonymous referees from Education Economics, Colin Green, Louis Levy-Garboua, Todd Lubart, Jean-Christophe Vergnaud and Marie-Claire Villeval for their useful comments that contributed to improving the paper.

${ }^{\dagger}$ Corresponding author: Noemi.Berlin@ed.ac.uk, University of Edinburgh, School of Economics, 31 Buccleuch Place EH89JT Edinburgh

${ }_{\ddagger}^{\ddagger}$ Université Paris 8, Laboratoire Parisien De Psychologie Sociale, jltavani@gmail.com

${ }^{\S}$ Université Paris X, maudbesancon.psy@gmail.com 


\section{Introduction}

Education has a major impact on economic outcomes, especially in the labour market.

Schooling choices should lead individuals to make optimal choices with respect to their abilities and environment. Differentials in this achievement are driven by many factors such as individual characteristics (own abilities, social background) as well as environmental causes (peer effects, neighbourhood effects) or reasons related to the way schools function (public vs. private, credit constraints, early or late specialization, available information, etc.). For a long time, cognitive abilities were assumed to be the main reason for success in school and in the labour market. ${ }^{1}$

In our modern society, where individuals have to adjust constantly to new problems and find original solutions, creativity is an important feature (Amabile, 1996a, $b$, Sternberg and Lubart, 1995). It is increasingly recognized as a key ability that promotes personal development, including academic achievement and performance (Besançon, Lubart and Barbot, 2013, Kim and Zabelina, 2011). Several papers have studied the relationship between creativity and academic achievement ${ }^{2}$; however, these were subject to a number of limitations including (1) using Grade Point Average (GPA) ${ }^{3}$ or self-reported grades (Kuncel, Credé and Thomas, 2005), (2) a self-reported assessment of creativity, and/or (3) a non-specific assessment of creativity. In our work, we aim to overcome these limitations by using both recent and ecological measures of creativity and the true grades over one school year. ${ }^{4}$

\footnotetext{
${ }^{1}$ In fact, we hypothesize here that there is a positive correlation between wages and school grades, through higher education attainment (Weiss, 1995, Altonji, 1995).

${ }^{2}$ see Ai (1999), Balgiu and Adîr (2014), Cicirelli (1965, 1966), Furnham, Zhang and ChamorroPremuzic (2006), Jackson (2013), Nami, Marsooli and Ashouri (2014), Sen and Hagtvet (1993), Yeh (2004)

${ }^{3}$ Studies that try to isolate predictors of academic success generally use the Grade Point Average (GPA), which is an average score based on different school subjects (language, mathematics, literature, chemistry, etc.). "Secondary subjects" such as music, arts or physical education are not included (Laidra, Pullmann and Allik, 2007, Richardson, Abraham and Bond, 2012, Steinmayr and Spinath, 2008). The GPA cannot thus be a total representation of schooling achievement as it excludes some of the teaching. Despite criticism of the accuracy and validity of this index (Didier et al. (2006), Johnson (2003)), it remains the most widely used assessment (Richardson, Abraham and Bond, 2012).

${ }^{4}$ We favour test scores over IQ level as they represent the real decisional component of educational choices. In fact, the decision to invest in an additional year of schooling mainly depends on test scores.
} 
This paper presents an analysis of the association between creativity and test scores, providing an insight into the role of creativity in the French educational system, which has become an important issue. Reports from the French Institute of Education (Ifé) question the part played by creativity in French schools. In their report of January $2012^{5}$ they describe the French educational system as formalized and organized in order to relay existing knowledge. Individuals are thought to be largely rewarded for conformity, which goes against learning creativity. This may be consequential in rapidly changing labour market where skills such as risk-taking, flexibility and creativity are likely to be valuable. The Ifé proposes a trade-off between innovation in terms of pedagogical tools based on learning creativity and traditional evaluation. This idea is still questioned in France, especially because school programmes are entirely established by the State. This means that changing any aspect of schooling pedagogy for most public schools is an administrative and legislative process (private schools or schools with specific pedagogies are excluded). This new dimension is rarely studied in economics although it strongly predicts innovation as this latter represents the successful implementation of creative ideas within an organization (Majaro, 1992, Antonites and Van Vuuren, 2005). Because creativity and innovation are related, and because innovation is a keystone of performing firms, the role of creativity as early as during childhood becomes an important dimension.

In this context, creativity is no longer considered exclusive to geniuses or eminent people, but is also a quality of ordinary people (Beghetto and Kaufman, 2007, Kaufman and Beghetto, 2009, Richards, 1999, 2010, Runco, 2004). Creativity is defined as the ability to realize a production (an idea or a concrete realization) that is original (new or unexpected) while remaining appropriate (useful or valuable) to the context in which it occurs (Runco and Jaeger, 2012, Sternberg and Lubart, 1995, 1999). "Everyday" creativity can be divided into creative performance (the actual manifestation of creative performance) and creative potential, which refers to the relevant dimensions (psychological characteristics of individuals, characteristics of the environment

\footnotetext{
${ }^{5}$ This report can be found in French at http://ife.ens-Iyon.fr/vst/DA-Veille/ 70-janvier-2012.pdf.
} 
and the type of mental operations conducted during the creation process) that lead to a creative performance not yet realized (Runco and Kim, 2011, Runco, 2007). Creativity is a multifaceted phenomenon (Zeng, Proctor and Salvendy, 2011): different factors contribute to creative potential. The differences observed between individuals result from a combination of cognitive, conative ${ }^{6}$ and environmental factors (Caroff and Lubart, 2012): thus this combination involves the study of the creative person, i.e. the study of psychological characteristics of individuals (Rhodes, 1961).

Although the analysis of the relationship between creative potential and academic achievement started in the $1960 \mathrm{~s}$, there is a more recent literature that focuses on the relationship between personality and educational outcomes or wages ${ }^{7}$. When the Five-Factor Model (FFM) of personality traits (the Big Five) is used (McCrae and Costa, 1987, John and Srivastava, 1999), conscientiousness consistently emerges as a stable predictor of exam performance (Chamorro-Premuzic and Furnham, 2003). The results of meta-analysis show that conscientiousness is a major determinant of academic success assessed by the GPA (Poropat, 2009, Richardson, Abraham and Bond, 2012). As mentioned above, openness to experience, as a personality trait, is a central dimension of creative potential (Feist, 1998, 2010) and appears to be the second best predictor of academic achievement. This centrality of openness to experience and conscientiousness was confirmed recently (Caprara et al., 2011, Di Giunta et al., 2013, Zuffianò et al., 2013) while the other Big Five dimensions (emotional stability, agreeableness and extroversion) seem to have little or no influence.

Some studies seem to show that creativity has an effect on academic achievement when participants reach a certain level of intelligence, measured by IQ (Getzels and Jackson, 1962, Torrance, 1962). However, these results are not robust over different papers, with some authors finding the exact opposite result (Yamamoto, 1964) while others show consistent results with a linear additive effect of creativity and intelligence on academic achievement (Cicirelli, 1965). Chamorro-Premuzic (2006), for instance, tried to identify the best predictor of academic success by comparing personality traits

\footnotetext{
${ }^{6}$ As opposed to cognitive factors, conative factors refer to personality traits and to motivation.

${ }^{7}$ See Poropat (2009), Richardson, Abraham and Bond (2012), Bowles and Gintis (1975), Bowles, Gintis and Osborne (2001), Heckman (2006), Heckman, Stixrud and Urzua (2006).
} 
and divergent thinking. It appeared to improve the prediction only when academic success was predicted through the writing of a master's thesis.

In our work, in order to identify a relationship between creativity and schooling achievement, in addition to traditional non-cognitive measures (personality traits) and individual characteristics, we collected data in the field from classes of a secondary school located in a Parisian suburb. Our sample consisted of six 9th grade classes that took the BB5, and we measured the pupils' creativity.

To measure school achievement, we obtained the pupils' report cards from the school detailing the average grades for every subject. The dependent variables are thus observed grades of the mandatory lessons i.e. mathematics, physics and chemistry, biology, French, foreign languages (FL), history and geography, music, art, IT and physical education (PE). Maths, French and foreign languages are considered the core subjects by the educational system, followed by physics and chemistry, biology, history and geography. The remaining four can be categorized as secondary. We also obtained the success rate of the final secondary school exam ("Brevet des Collèges") and were thus able to estimate the probability of success.

Based on our specific sample, we find a weak correlation between our creativity measures and personality traits except for openness, which reinforces the independent role of creativity and also the fact that a greater openness to experience is generally associated with a higher creative potential (McCrae and Costa, 1987).

The main result of our paper is that creativity has an ambiguous relationship with school achievement. First, verbal divergent thinking is negatively associated with almost all of the subject grades. However, graphical integrative effects are positively associated with scientific subjects. These results highlight the fact that in order to obtain good grades at school, it is necessary to restrain divergent thinking. Second, when looking at the probability of passing the final secondary school exam ("Brevet des Collèges"), we find that verbal divergent thinking no longer has any effect, but that both types of integrative thinking increase this probability. We thus provide evidence of associations between creativity and schooling achievement but we do not provide any causal effect from one to the other. Hence, there might be unobserved 
variables that would affect both creativity and grades such as cultural activities (going to the museum, playing an instrument), having personal tutors, or any cultural capital inherited from the parents that we do not measure ${ }^{8}$ that could bias the estimates. Even though estimates may include a positive bias, we believe the relationship we find between creativity scores and school achievement are quite new for this literature

Openness, and to a lesser extent conscientiousness and agreeableness, exhibit significant positive estimates on grades, but predict to a lesser extent the probability of succeeding in the final exam. An inconsistency variable, coming from a risk aversion elicitation measure (Holt and Laury, 2002), is negatively associated with scientific grades.

Overall, girls have significantly higher test scores than boys, except in sports. This might explain the fact that contemporary girls often choose different paths and stay in school longer than boys. ${ }^{9}$ Moreover, girls have higher scores of both divergent and integrative verbal thinking compared to boys. An interesting result emerges from the analysis of the probability of exam success: all things being equal, boys have a higher probability of passing the exam, although girls have higher grades during the school year. We discuss different explanations for this result.

This paper is organized as follows: section 2 presents the theoretical background and the estimation strategy, section 3 describes our data and how they were collected. Section 4 presents our results. Finally section 5 discusses the results and section 6 concludes.

\footnotetext{
${ }^{8}$ A relatively low proportion of our sample (24\%) were involved in cultural activities such as playing an instrument. Field data could overcome this issue if we had the parents to fill in some questionnaires as well. Unfortunately this is not the case. So we cannot exclude unobserved factors in our error terms.

${ }^{9}$ We do not take into consideration here the stereotypes that girls and boys may encounter when choosing specialities.
} 


\section{Theoretical framework and empirical strategy}

\subsection{Creative potential}

This subsection presents the theoretical background of creative potential based on the psychology literature.

\section{Cognitive factors of creativity}

Cognitive factors refer to knowledge and information-processing abilities that facilitate inventive thinking. The environment influences not only the development of creative capacities but also the various forms that creative expression may take. The environmental influence occurs in different spheres: the family, the school or work environment and the cultural context in which the person evolves. These various environments are embedded in each other. Among these cognitive components, general intelligence and divergent thinking are the most investigated. Divergent thinking can be defined as the cognitive ability to produce numerous responses in various directions for one task (Guilford, 1967, Runco and Kim, 2011). It is a classic and central component of creative potential (Guilford and Hoepfner, 1971, Lubart, 2001, Runco, 2004, Runco and Kim, 2011). Creative achievement, or performance, appears to be associated more strongly with divergent thinking than with intelligence (Kim, 2008). However, creative potential cannot be summarized as divergent thinking; it also requires an ability to summarise different ideas into a single original and adapted production. (Besançon, Lubart and Barbot, 2013, Cropley, 2010). This distinction opposes divergent thinking, in which the goal is to explore multiple cognitive paths, and convergent thinking, which seeks to focus on a single, perhaps optimal path. Complex creative performance tasks certainly involve both kinds of process, in various degrees and in specific sequences that favour the generation of new ideas in a task. In this vein, Lubart and Guignard (2004) proposed that the moderate correlations observed between different creative performance tasks stem from the fact that there is a different mix of cognitive operations and knowledge involved in each creative domain 
and task.

\section{Conative factors of creativity}

Conative factors of creativity refer mainly to personality and motivation (Lubart and Mouchiroud, 2003). Here, we focus on personality traits because they define "what a person will do when faced with a defined situation" (Cattell, 1979). These are relatively stable characteristics of the individual, while motivation is more contextual and specific to narrow domains. The Five-Factor Model (or Big Five Model) proposes a structure of human personality in five bipolar dimensions: extroversion (vs. introversion), agreeableness, conscientiousness, emotional stability (vs. neuroticism), and openness (or intellect). Extroversion is revealed through a higher degree of sociability and talkativeness. Agreeableness refers to someone who is helpful, sympathetic, and cooperative. A conscientious person can be exemplified by someone who is disciplined, organized, and achievement-oriented. Emotional stability refers to someone who can control his/her impulses and anxiety. Openness reflects intellectual curiosity and the preference for novelty and variety and is systematically associated with creativity.

In conclusion, it appears that creative potential is based on a set of features, some of which are more central than others: namely, divergent thinking, integrative thinking, and openness, which will be assessed in this study.

\section{A production function for educational achievement}

We use an education production function (Van Klaveren, 2011, Cunha and Heckman, 2007) with different inputs: creativity (four scores), personality traits (non-cognitive abilities) and individual characteristics (gender, age and parental background), the outcome being schooling achievement measured by the test scores in different subjects.

$$
T_{i j c}=\beta_{i j} C_{i c}+\gamma_{i j} P_{i c}+\lambda_{i j} X_{i c}+\alpha_{c}+\epsilon_{i j}
$$

where $T_{i j c}$ is the observed test score for a pupil $i$, in a subject $j=$ maths, French, history and geography etc... $\}$ and in a class $c . C_{i c}$ is the vector of the individual creativity scores (see section 3 for the data description), $P_{i c}$ is a vector of 
the five personality traits (BB5), $X_{i c}$ is the other observed covariates (gender, age, inconsistency from a lottery task, teachers' characteristics) and $\alpha_{c}$ is the class fixed effect (in order to control for any unobserved heterogeneity coming from the class). $\epsilon_{i j c}$ is assumed to be normally distributed with a mean of zero and variance $\sigma_{\epsilon}^{2}$.

We want to test the assumption that pupils' performance depends differently on various cognitive and non-cognitive abilities. In contrast to Cunha and Heckman (2007), our model is not dynamic and we will explain test scores of a single school year ${ }^{10}$. Standardized test scores are our main output and will first be our dependent variables in an OLS regression. However, we will assume the error terms to be correlated across separate but related regressions, each estimating test scores in different subjects. In that case, we will present our main results through SUR (seemingly unrelated regression) on test scores as there can be correlated unobserved variables in the error terms.

An additional problem of measurement error could arise from our field data. As explained in the next section, we used assessment tools that have good psychometric properties (cf.American Educational Research Association, American Psychological Association and National Council on Measurement in Education (1999)). In the classic psychometric approach, psychometric properties enable the measurement error to be evaluated. Reliability, in particular, is the property that estimates the measurement error. The assessment tools we used for our study are validated psychometric measures, in the French context, and are robust; in other words, the measurement error is, on average, biased toward zero (Barbot, 2012, Lubart, Besançon and Barbot, 2011).

In a later section, we estimate the probability of passing the national secondary school exam. For the pupils in our dataset, we have a binary outcome variable indicating passing or failing this exam. We will run a probit on the binary variable of succeeding the exam $\left(Y_{i}=1\right)$ or failing the exam $\left(Y_{i}=0\right)$. Marginal effects from the probit will be reported.

\footnotetext{
${ }^{10}$ In a dynamic setting, the following year's test scores $(t+1)$ could be explained the grades at $t$ and the same cognitive and non-cognitive abilities.
} 


\section{The data}

Data were collected on six 9th grade classes from a middle school in Rosny-sous-Bois (a Parisian suburb) in January and February 2012. The whole procedure consisted of four steps. The first two corresponded to the measurement of creativity, the third step was the personality test (the BB5 based on the Big Five inventory) and a measure of risk aversion based on the Holt and Laury (2002) task. The last one consisted of collecting the school grades of each student in each subject, which reflect schooling achievement and their cognitive skills. The following subsections describe each step.

\subsection{Measuring creativity using the Evaluation of Potential Cre- ativity (EPoC) procedure}

There are many different tests of creativity, which has proved to be a difficult psychological concept to measure. Some are based on completing tasks (for instance, the Torrance Test of Creative Thinking, Torrance (1962)) and some are self-assessed (The Adjective Check List, Zuckerman and Lubin (1965)). When based on performing tasks, the existing tests yield scores of divergent thinking (verbal and graphic), but not integrative thinking. In our opinion, it is important to consider both dimensions as they represent two types of skills equally important for creative potential.

EPoC (Lubart, Besançon and Barbot, 2011) is a procedure to measure the creative potential of pupils from elementary to middle school. It is a synthesis and extension of several traditions of measurement, which is based on a current theoretical framework seeing creativity as a multi-faceted, domain-specific construct that involves many components. Through this procedure, it is possible to categorize the numerous micro-processes involved in creative potential into two main sets, called divergent-exploratory processes and convergent-integrative processes. Moreover, as creativity is domain-specific, it is important that measures of creative potential take into account the domain of creative expression. Consequently, EPoC measures both sets of micro-processes: divergent thinking (DT) and integrative thinking (IT), based on two different domains of expression: verbal and graphic. This contrasts with other 
existing measurement tools that focus on only a single component of creativity with a global approach and tend to generalize the observed results to any domain of creative expression. A detailed description of the tasks and some pupil outputs can be found in the appendix of part 2 of this paper.

Divergent thinking (DT) is a thinking process consisting of generating a maximum of creative solutions. The EPoC procedure embodies two types of DT:

- Graphical Divergent Thinking (hereafter GDT): pupils are asked to produce a maximum of original drawings in 10 minutes based on a simple shape.

- Verbal Divergent Thinking (hereafter $V D T$ ):the experimentalist gives the beginning or end of a story and pupils are asked to produce a maximum number of story endings or beginnings in 10 minutes.

Integrative thinking (IT) is a cognitive activity that consists of combining many elements. Two types of IT are distinguished:

- Graphical Integrative Thinking (hereafter GIT): from ten drawings, pupils are asked to produce one unique drawing, the most original, using at least three drawings from the list in 10 minutes.

- Verbal Integrative Thinking (hereafter $V I T$ ): the experimentalist gives a story title and the pupils have 10 minutes to finish the story in the most original manner.

The external validity of the procedure was confirmed by Lubart, Besançon and Barbot (2011) by measuring creativity with EPoC as well as replicating a measure of creativity by Torrance (1962): this test is also known as the "cardboard box" where subjects have 10 minutes to suggest a maximum of possible uses of the box, hence categorized as a divergent thinking task. It showed a high and significant correlation with the divergent thinking tasks of EPoC. There are well known results showing a low correlation between IQ tests and creativity measures. Hence, IQ tests were run on children who also took the EPoC tests, confirming this result. Finally, subjects 
also took the BB5 test (described in the next section). Lubart, Besançon and Barbot (2011) found a correlation between the trait of openness and creativity dimensions, which is consistent with the results of McCrae and Costa (1987) showing that this personality trait facilitates the efficient use of divergent thinking so that it is as creative as possible. The external validity of the EPoC procedure is thus well established.

Two sessions were organized to measure creativity. ${ }^{11}$ During each session, each type of creative thinking was measured (see figures 4, 5, 6 in the appendix for different outputs of VIT, VDT and GIT). Each session lasted on average 50 minutes and was run in the classroom with paper, pencils and felt pens. To summarize, in the DT tasks, pupils were asked to produce a maximum of ideas, responding to a unique stimulus. In the IT tasks, they had to produce a more developed synthetic solution.

Creativity scores for each type are based on the number of outputs (for DT tasks) and the degree of originality. The higher the score, the higher the individual's creative potential. In order to simplify the analysis, we use standardized scores of these four measures. 81 pupils completed the whole test (over both weeks). Figure 1 shows the distribution of the four creativity scores.

[Figure 1 about here]

Clearly, higher integrative thinking is more frequent than divergent thinking, whose distribution is more shifted to the left on the distribution graph. This already signifies that children are better at integrative thinking than at divergent thinking. Lubart, Besançon and Barbot (2011) suggested that integrative thinking (especially verbal) develops earlier than divergent thinking. Even though this has still not been totally confirmed, it might explain why this kind of distribution is observed. The remaining question is to see whether these creativity dimensions have an influence on schooling achievement.

\footnotetext{
${ }^{11} \mathrm{~A}$ different version (A and $\mathrm{B}$ ) was used in each session in order to obtain robust scores of creativity. The tasks were the same overall but the content differed (types of drawing, titles of the stories).
} 


\subsection{The BB5 questionnaire}

In this study, the five personality traits: Agreeableness, Conscientiousness, Extraversion, Emotional Stability and Openness (as in the Big Five inventory) were measured by the Brief Big Five measure (Barbot, 2012), which was constructed specifically for children and teenagers. This questionnaire consists of a list of 100 adjectives. For each adjective, the pupil states, on a five-point Likert scale, if the adjective describes her/him totally or not at all, with three intermediate possibilities. Pupils were allowed to ask questions if they did not understand an adjective. A unique score is obtained for each trait, highlighting the personality traits that characterize the individual.

After the BB5 questionnaire, pupils were asked traditional demographic questions about their gender, age, parents' education, etc. 99 pupils took this test on a computer notebook in the classroom. There are validity criteria based on missing entries, "non-positioning/doubts" (this is the tendency to give central answers rather than positioning oneself in agreement or disagreement), and the tendency of agreement (a high frequency of total agreement or disagreement). These last two criteria yield a score that enables valid scores to be determined. Three pupils did not finish the questionnaire and five did not have valid scores. Consequently, 91 observations were usable for analysis based on the BB5 questionnaire.

\subsection{Inconsistency measure}

We implemented a risk aversion elicitation rule as in Holt and Laury (2002) right after the BB5 questionnaire. Pupils had to make ten choices between two lotteries (see Figure 2). Probabilities were the same for each choice; only the amount of money changed.

[Figure 2 about here]

Lotteries were presented as scratch cards while the probability of winning was presented as the chance of winning. Pupils were allowed to ask questions about the task, which enabled us to check that they understood the instructions and the task 
quite well. We are interested here in the inconsistency yielded by this measure. The level of inconsistent choices observed is $26.3 \%$. Inconsistent participants are those who exhibit multiple switches or inconsistent choices (like choosing option A in the last row $)^{12}$. This inconsistency level does not differ significantly from previous studies carried out on adults (Ballinger and Wilcox, 1997, Blavatskyy, 2010, Lévy-Garboua et al., 2012, Loomes and Sugden, 1998). In this study, we use the inconsistency as a proxy of a certain type of cognitive ability relying on the assumption that pupils who are considered inconsistent either did not understand the task or have trouble with computing probabilities.

\subsection{Grades collected}

In order to measure schooling achievement, the average grades of every pupil for each subject and each trimester of their 9th grade were collected. The mandatory lessons of middle school were used i.e. mathematics, physics and chemistry, biology, French, history and geography, foreign languages, arts, music, IT and physical education (PE). These were divided into three categories: scientific subjects, the humanities and secondary subjects (see Table 1).

[Table 1 about here]

As Table 1 shows, between 92 and 97 observations were collected for the fundamental lessons. However, even though the secondary subjects are mandatory, some pupils may skip them, explaining the low number of observations for these lessons. This may indicate that they are underestimated and considered less important than the other subjects.

There are six 9 th grade classes named A to F. In France, pupils are graded on a 20-point scale. ${ }^{13}$ Table 7 in the appendix reports all the average grades in each class

\footnotetext{
${ }^{12}$ We allow pupils who switch three times to be consistent, considering that they might be indifferent between the first and third switch. For these individuals, their certainty equivalent is situated between the first and third row.

${ }^{13}$ Each teacher (of the different subjects) comes up with their own tests. For our analysis, we standardized the test scores. For every school grade and subject, there is a specific programme to
} 
for each subject considered. Some classes have higher average grades than others. This could be due to peer effects ${ }^{14}$ or because grading exams varies within teachers (teacher effects). We checked for each teacher in each class and subject and found that when there are differences between average grades of classes, it is not because one teacher grades his/her classes differently but because the teacher is different. Hence, when classes have the same teacher, the average grades are almost the same. In order to control for any peer effects, class fixed effects are included in the regressions.

At the end of their 9th grade, the pupils take the compulsory secondary school final exam ("le Brevet des Collèges") that delivers a diploma. It contains three tests: in maths, French, and history \& geography. Success in this exam is partly based on the grades obtained in these written exams and partly on continuous assessment during the 9 th grade. Each of these evaluations contributes $50 \%$ to the final grade that leads to a diploma.

Nowadays, this exam has become informal and it is possible to move on to high school without passing it. Nevertheless, most pupils still take it. Information was obtained for 125 pupils on whether they passed it or not ${ }^{15}$, and whether they achieved a distinction, but not on their exam grades. This exam is anonymous and pupils are graded by external teachers who do not know the name or gender of the pupil.

For pupils whose grades will be used in the following section, their success rate is $71.6 \%$. This is fairly low as the national success rate for this diploma has been between $80 \%$ and $85 \%^{16}$ in the last ten years ${ }^{17} .64 .6 \%$ of them obtained a distinction ${ }^{18}$.

follow established by the French Ministry of National Education. It is known by all teachers and it is their duty to follow it so we can assume that tests are standard.

${ }^{14}$ Hoxby (2000) and Markman et al. (2003) found that peer achievement has a positive effect on students' own achievement.

${ }^{15}$ Even though we did not obtain some pupils' grades, they still took the exam. The mean average given is on a 40-point basis that can easily be converted to a 20-point scale. An average grade of $20 / 40$, based on continuous assessment and exam grades, is required to pass this exam. Scoring 0/40 in one of the subject tests leads to immediate failure.

${ }^{16}$ This information is available on http://www.education.gouv.fr/cid59753/diplome-national-dubrevet.html

${ }^{17}$ This is an indication of the school level being rather low.

${ }^{18}$ There are three distinctions for the French diploma: the lowest (cum laude) is awarded for an average grade between $12 / 20$ and $14 / 20$, the second (magna cum laude) for an average grade between 


\section{Results}

We estimate the education production function of section 2 in which creative potential is the input of interest. Personality and other individual characteristics enable previous results to be controlled and replicated, increasing the robustness of the creativity estimates. First, we highlight who might be creative pupils.

As we went to the middle school three times, we faced the problem of selection bias. In fact, pupils who attended the three sessions are those who do not skip classes and so they can be considered more conscientious and regular. ${ }^{19}$ Of the 99 pupils who attended the BB5 session, 81 attended the creativity sessions. Overall, the pupils who attended the three sessions have significantly higher grades than those who did not. 20

\subsection{Who are the creative pupils?}

Before providing further estimates on the relationship between creativity and schooling achievement, in this subsection we aim to have a broader idea of who the creative pupils are.

Some personality traits are usually associated with creative potential such as openness or individualism. Table 2 reports the correlation coefficients between the creativity variables and the personality traits.

\section{[Table 2 about here]}

The correlation coefficients are overall in line with the results of Barbot (2012), who mainly found a high correlation (significant at a 5\% level) between openness and GDT, VDT and VIT, and also a correlation between extraversion and GDT $^{21}$. In our case, openness is highly correlated with both the verbal tasks and extraversion

$14 / 20$ and $16 / 20$ and the highest (summa cum laude) for an average grade higher than $16 / 20$.

${ }^{19}$ However, a two-tailed t-test on the score of conscientiousness between those who attended the creativity sessions and those who did not yielded a $\mathrm{p}$-value $=0.39$.

${ }^{20}$ Two-tailed t-tests on the standardized grades for each subject yielded a p-value $<0.1$ except for biology and sports.

${ }^{21}$ His study is based on 607 teenagers. 
is correlated with VDT. We also find a weak correlation between agreeableness and verbal tasks, but not as significant as the other correlation coefficients.

Therefore, openness seems to be more correlated to all subtypes of creativity compared to the other personality traits. This is consistent with the result that openness facilitates the use of divergent thinking for more creative production (McCrae and Costa, 1987). This is also the case for integrative thinking. Creativity can thus be considered a cognitive ability that is rather poorly correlated to personality traits. They are independent variables, thought here to play a role in schooling success.

Higher scores are found for integrative thinking (both graphic and verbal). Do girls and boys exhibit the same degree of creativity? Figure 3 displays the distribution of each creativity score by gender.

[Figure 3 about here]

Overall, creativity score distributions are more shifted to the right for girls, which implies higher creativity scores than for boys. This is less clear for the GIT dimension where both distributions look alike (except for the peak for girls where $30 \%$ of the sample has a 0 standardized score of GIT). In fact, two-tailed t-tests reveal that scores in GIT are not significantly different between boys and girls $(p=0.83)$, which is also the case for the GDT scores $(p=0.14)$. However, for both verbal tasks, girls have a higher score than boys (for the VIT score the $p$-value $=0.001$ and for the VDT score the $p-$ value $=0.06)$.

Baer and Kaufman (2008) review the topic of gender differences in terms of creativity. Among the different studies published, the results are not always consistent, mainly because of the multiple creativity measures used. Nevertheless, the general trend seems to be that women and girls have higher creativity scores than men and boys. 


\subsection{Estimation of test scores}

In this section, we run regressions on the standardized average test score in different subjects for the whole 9 th grade year ${ }^{22}$ (three school terms). We pool scientific subjects (maths, physics and chemistry, biology) and humanities (French, history and geography, foreign language $)^{23}$.However, we use the test scores of the "secondary" subjects individually (arts, music, IT and physical education). We run seemingly unrelated regressions (SUR) as we assume that the error terms of the various equations we estimate are correlated. For every SUR we perform, Breusch-Pagan tests yield a p-value $<0.001$ implying auto-correlation of the errors. We present the estimated coefficients from SUR in Tables 3 and 4.

In Table 3 class fixed effects are introduced in columns 3 to 10 . We also ran OLS regressions on the same test scores; the results can be found in the appendix in Table 8. Coefficient and standard errors are slightly higher in OLS. We will focus on the SUR.

Overall, the verbal divergent thinking estimates are negatively and significantly associated with sciences, humanities, music and IT. Divergent thinking was the first dimension studied by psychologists to evaluate creative potential. It is considered essential for creative processes and can be seen as the basic ability that allows the creation of alternative solutions to a given problem. Estimations reveal that, in this school, the higher the VDT score, the worse the pupil's test scores. This suggests that the grading system does not encourage the use of divergent thinking abilities, which are fluency, flexibility and originality. It might mean that the school's teachers evaluate pupils in a quite conservative way, which supports the criticism that is sometimes made of the French education system.

[Table 3 about here]

[Table 4 about here]

\footnotetext{
${ }^{22}$ There are no significant trends over the year meaning that pupils overall exhibit constant grades during the school year. Thus, we can compute the year's average test scores.

${ }^{23}$ We also ran the same regressions on the test scores for each subject but we found that it did not change the main results so, to have greater power in our data, we pooled them by field of study.
} 
Graphical Divergent Thinking exhibits a positive and significant effect for the scientific study field. Separate estimates (not reported here) on the specific subjects shows that these results are actually driven by the biology test scores in which pupils are often asked to draw and represent their knowledge in graphics. It is also positively associated with the music and IT test scores. Otherwise, the other dimensions of creativity have no effect on our variable of interest. The non-significant effect of the graphic dimensions may be due to the fact that, at this age, pupils have to invest more in verbal domains than in graphic domains. Even when pupils have a high score in graphic thinking, it might just not be needed to perform well at school.

In terms of personality, openness is positively associated with almost all the grades. This is consistent with the literature on this trait. Previous research has found that openness, which reflects curiosity, imagination, and unconventionality (also sometimes called intellect or openness to new experiences), is correlated with intelligence scores. A higher score of conscientiousness and agreeableness also increases the grades in sciences and humanities (when parental background is not included), music and IT. Coefficients fluctuate between 0.02 and 0.03 , which is much smaller than the VIT coefficients (between 0.07 and 0.12).

Blickle (1996) showed that conscientiousness and openness have an effect on learning strategies. ${ }^{24}$ Goff and Ackerman (1992) and Ashton et al. (2000) also showed that openness and intellectual ability are positively correlated. Having a higher score of openness is hence rewarded by better test scores in our sample. However, having a high score of VDT is not, even though openness is positively correlated with this dimension. This might be explained by the fact that schools ask pupils to manifest curiosity, imagination and a taste for novelty but to comply with specific learning methods. This is incompatible with divergent thinking, which relies on the ability to consider a problem from different and new perspectives.

Controls for parental background are included in the last column of our tables. Because parental education was self-reported by pupils, many data are missing. More-

\footnotetext{
${ }^{24}$ They use scales to evaluate various strategies such as cognitive learning strategies, or resourcerelated leaning strategies.
} 
over, our data come from a low social background area. Hence, for the reported answers, we do not have a very balanced sample of qualified and low-qualified parents. $71 \%$ of fathers and $65 \%$ of mothers are low-qualified. Nevertheless, the mother's education seems to have a significant effect on the science test scores whereas the father's education is positively associated with the humanities field.

Inconsistency, a dummy variable coming from a lottery task that we consider a cognitive ability of understanding and computing probabilities, is negative and significant for sciences but not significant for humanities or secondary subjects, which is consistent and eliminates some of the possible unobserved factors.

Girls have higher test scores in every field except IT and physical education; coefficients are positive and significant at a $1 \%$ level. Table 7 in the appendix presents the distribution of grades for each subject between girls and boys. The distribution of girls' grades is shifted more to the right than that of the boys' grades. This may not be surprising as girls are considered more attentive, focused and self-disciplined (see Costa Jr, Terracciano and McCrae (2001), Rubinstein (2005)). In our sample, girls are significantly more agreeable, more open and slightly more conscientious (see Table 6 in the appendix for details). It is usually asserted that girls have better grades because they are more conscientious. Even though we controlled for these traits, we still find a large significant difference between boys' and girls' test scores. Hence, the gender hints at a mechanism not captured by all the variables controlled for. Researchers have investigated the issue of stereotyping in schools. By comparing non-anonymous vs. anonymous exams, they tested the assumption that girls are either positively or negatively discriminated by their teacher. Both Lavy (2008) and Falch and Naper (2013) found that girls outperform boys in almost all subjects and suggested that the bias found against male students is the result of teacher behaviour. ${ }^{25}$ One reason for this could be that girls and boys invest differently in the subject according to the teacher's gender. In fact, the way students perceive their teacher seems to have an impact on their motivation and performance (Maehr and Midgley, 1991, Meece, Glienke and Burg, 2006). A paper by Dee (2007) shows that teachers perceive their

\footnotetext{
${ }^{25}$ The former study was run on Israeli data and the latter was carried out in Norway.
} 
students better when they have the same gender as the teacher.

Ouazad and Page (2013) shows that, in school, boys invest less when they are graded by a female teacher and girls invest more when they are graded by a male teacher. Our sample size is rather small and comes from only one school but we have information about the gender of the teachers. Although there are three different maths teachers, they are all women. There are two different physics teachers, a man who teaches four classes and a woman teaching two classes. However, even when we control for the teacher's gender (columns 9 and 10 of Table 3 and columns 9 to 13 of Table 4) the coefficient for girls is still highly significant.

The assumption of favouring girls can be tested by looking at the probability of success in the national anonymous exam, estimated in the following section.

\subsection{Estimation of the probability of passing the compulsory secondary school final exam}

We are interested in explaining the probability of succeeding in this exam. We use the same independent variables as in the previous section.

Table 5 reports the marginal probability effect coefficients based on a probit on the dummy variable of passing $(=1)$ or not $(=0)$ the exam. As age seems to matter here (which is not the case in our previous analysis on grades), we create a dummy variable equal to 1 if the pupil is older than 14 . The usual age in 9 th grade is 14 or 15 years old. Being older can mean either being born at the very beginning of the year or repeating a grade, while being younger means skipping one grade. ${ }^{26}$

Passing this exam also depends on a continuous assessment based on 9th grade scores. These data were not available. In order to take this into account, we assume that having good grades during the year increases the probability of passing the exam. Hence, a rather good control for this is to add the average grades during the year. We

\footnotetext{
${ }^{26}$ We did not have access to their exact date of birth but the sessions during which we asked their age were run on January 24 th and 25th. The distribution of age is the following: $2.7 \%$ of our sample is $13,64.0 \%$ is $14,28.0 \%$ is 15 and $5.3 \%$ is 16 . The 16 year olds and most of the 15 year old pupils are likely to be repeaters.
} 
choose to add those in scientific subjects and humanities as a proxy for continuous achievement. Indeed, pupils with a higher average grade in sciences and humanities will have higher grades in their continuous assessment.

The interesting result given by this table is that variables associated with the probability of passing the national exam are not the same as for obtaining better grades during the school year. Column (1) reports the estimates of the marginal probability effects when creativity and personality are not taken into account. If the average grade in scientific subjects increases by one unit, then the probability of passing the exams increases by 14 percentage points. However, humanities grades have no impact even though there is one test in French and one in history \& geography. Interestingly, being older than 14 compared to being 14 and younger decreases the probability of passing the exam by 46 percentage points.

\section{[Table 5 about here]}

Column (2) introduces the personality traits showing a positive effect of agreeableness and openness on the probability of passing the exam, although it is quite small (0.011 and 0.026, respectively). Column (3) introduces creativity scores. Surprisingly, the creativity dimensions that have a positive impact here are both verbal and graphical integrative thinking with a moderate effect on the probability of passing the exam (a 5 percentage point increase in the probability of passing with an increase in the GIT score and a 7.7 percentage point increase with an increased VIT score). As mentioned before, we expected this creativity dimension to be positively associated with schooling grades. However, we have found previously that VIT has no significant effect on grades. Moreover, the VDT estimate is not significant here but was negative and significant in the previous analysis on schooling grades. This raises the question about the abilities needed for achievement during the year and during an anonymous national exam. Does schooling limit the use of VIT during the year even though it is necessary in order to succeed in an exam (where pupils must have a global knowledge based on many years of studies)?

Concerning girls, another interesting result emerges. The estimated coefficient of 
the girls' dummy variable is negative and significant (at a $10 \%$ level) meaning that, all things being equal, being a girl decreases the probability of passing the exam by between 12 and 18 percentage points compared to boys. ${ }^{27}$ Nevertheless, we showed in the previous subsections that they had a higher score for VIT and better grades. Indeed, $63 \%$ of boys passed the exam compared to $71 \%$ of girls. The negative estimates indicate that if we compared a boy and a girl with the same level of ability, creativity and personality, the boy might succeed better. This will be discussed below.

\section{Discussion}

In France, orientation choices, which occur at the end of secondary or high schools, are made before taking the national exams ("Brevet des Collèges" and "Baccalauréat"). are based on the schooling grades and not on the exam scores. ${ }^{28}$ Succeeding in national exams is only needed in order to pass to the next educational level. ${ }^{29}$ Hence, explaining schooling grades remains the first issue to consider, followed by exam success.

Openness and conscientiousness seem to be the main predictors of better schooling grades. As openness contributes to creativity, we could think that originality is rewarded by better grades. Teenagers with a high score of openness are curious and seek new experiences. They can be considered eager to learn, artistic and imaginative. Nevertheless, we find that a higher score of verbal divergent thinking decreases grades. This raises the question of which type of creativity is beneficial to the pupils in school. From our study, it seems that open pupils have better grades if they manage to stay in line with the standard learning strategies. Would the French educational system be considered less conventional if new learning tools focused on the development of creativity? This remains an open question and further studies are needed, especially

\footnotetext{
${ }^{27}$ These coefficients are not very stable because of our limited sample but still give an idea of what can occur in this situation.

${ }^{28}$ These decisions might, however, be influenced by the exam results ex post, but this concerns a marginal number of pupils.

${ }^{29}$ In fact, it was mandatory to pass the middle school exam, and it is still mandatory to pass the high school exam in order to reach higher educational levels.
} 
if creativity really represents an important skill when entering the labour market.

Concerning the gender effect, we observe that girls have better grades during the school year. We ran the same regressions for girls and boys separately. Because this leads to a very small sample, we do not report the tables ${ }^{30}$ but we assume that doing so at least gives a hint of the possible differences between boys and girls. For scientific subjects, a significant positive effect of GIT is only found for girls. The conscientiousness coefficient is positive and slightly significant for girls in their maths score. Inconsistency seems to have a negative effect on boys' scientific grades implying being inconsistent in the lottery task decreases the grades. However, it is not significant for girls. For the humanities and the scientific subjects, conscientiousness positively drives girls' results, but has no effect on boys. In arts and music, openness is positively associated with grades for both boys and girls and there is a positive coefficient of conscientiousness for girls' grades in music. It seems that personality traits, especially conscientiousness, are mainly correlated to girls' grades.

Regarding the national exam, we find that girls do not succeed better in the exam when compared to boys with the same level of abilities. We suggest different explanations that we are unable to confirm due to the lack of available data but that can be further explored: girls can crack under the pressure of this national exam more than boys and thus succeed less. Another possible explanation is that girls are more hard-working and conscientious during the whole year leading to better results during the year. Yet, boys may perform better when studying for the exam and will then outperform girls. Lastly, our result could also be explained by the idea developed by Lavy (2008) and Falch and Naper (2013) i.e. teachers give higher grades to pupils when they know they are girls, implying a negative bias towards boys. In an anonymous exam, this positive discrimination is not possible.

\footnotetext{
${ }^{30}$ Available upon request.
} 


\section{Conclusion}

This paper establishes a link between academic achievement and creativity, controlling for personality traits. The impact of creativity on schooling achievement has rarely been studied in the growing economic literature on the analysis of non-cognitive abilities and educational outcomes. We went into the field, in a middle school, where we were able to measure the creative potential of 9th graders, and obtained four scores of creativity subtypes: verbal divergent thinking, graphical divergent thinking, verbal integrative thinking and graphical divergent thinking. It should be noted that our sample has few observations and comes from a low socio-economic status ${ }^{31}$, so one must be careful when extending the results.

Academic achievement was assessed from the report of test scores of their 9th grade for mandatory lessons. We could have expected creativity to play a role in gaining better grades, at least in the creative subjects such as arts and music. We find that the different subtypes of creativity do not affect grades in the same way. Verbal divergent thinking predicts test scores significantly and negatively. This result suggests that this is not a skill required to succeed at school. However, it is required in many innovative domains such as $R \& D$. We were also able to estimate the probability of passing the "Brevet". In contrast, a higher score of integrative thinking increases the probability of succeeding, but being a girl does not.

We also confirm previous work on the relationship between personality traits and schooling achievement: conscientiousness and openness are the main traits that positively influence grades.

From these results, we are able to present some recommendations for future studies on schooling achievement. One relates to taking into account the specificities of the different learning domains. Ability and success cannot always be considered globally. An IQ test, GPA or other global maths or word task tests are not able to highlight this specificity. As we saw previously, different individual variables impact schooling

\footnotetext{
${ }^{31}$ We asked pupils the socio-professional category of their parents as well as their exact job. We were then able to establish the proportion of highly qualified mothers and fathers in our sample, which is $35.4 \%$ and $29.1 \%$, respectively.
} 
grades in different ways.

It might be of interest to obtain a deeper understanding of the role of creativity in school, at different levels of education, and its implication for the labour market. New data collection could overcome the endogeneity problem and non-observed variables so one can test for any causal effect from creativity to school achievement. Second, gender is a key variable that might imply other underlying behaviours or mechanisms.

Further development could involve replicating the same study in different schools and pedagogies, with different types of pupils (different social backgrounds and neighbourhoods), and even abroad where different educational systems are assumed to emphasise creativity more. We may then be able to describe the profiles of creative pupils: who are the most creative? Is there a relationship between being creative and a dropout? Do the creative pupils have different grade profiles from the other pupils? These are the remaining questions we would like to answer. 


\section{References}

Ai, Xiaoxia. 1999. "Creativity and academic achievement: An investigation of gender differences." Creativity Research Journal, 12(4): 329-337. 2

Altonji, Joseph G. 1995. "The Effects of High School Curriculum on Education and Labor Market Outcomes." The Journal of Human Resources, 30(3): pp. 409-438. 2

Amabile, Teresa M. 1996a. "Creativity and innovation in organizations." Harvard Business School Background Note, 396-239: 1-15. 2

Amabile, T M. 1996b. Creativity In Context: Update To The Social Psychology Of Creativity. Boulder, Colorado:Westview Press. 2

American Educational Research Association, American Psychological Association, and National Council on Measurement in Education. 1999. Standards for Educational and Psychological Testing. Washington, DC:American Educational Research Association. 9

Antonites, A.J., and J.J. Van Vuuren. 2005. "Inducing entrepreneurial creativity, innovation and opportunity-finding skills." SOUTH AFRICAN JOURNAL OF ECONOMIC AND MANAGEMENT SCIENCES, 8(3): 255. 3

Ashton, Michael C, Kibeom Lee, Philip A Vernon, and Kerry L Jang. 2000. "Fluid intelligence, crystallized intelligence, and the openness/intellect factor." Journal of Research in Personality, 34(2): 198-207. 19

Baer, John, and James C Kaufman. 2008. "Gender differences in creativity." The Journal of Creative Behavior, 42(2): 75-105. 17

Balgiu, Beatrice Adriana, and Victor Adîr. 2014. "Creativity Tasks and Academic Achievement. A Study on Romanian Politehnica Undergraduate Students." Procedia - Social and Behavioral Sciences, 116: 924-928. 2

Ballinger, T. Parker, and Nathaniel T. Wilcox. 1997. "Decisions, Error and Heterogeneity." Economic Journal, 107(443): 1090-1105. 14 
Barbot, B. 2012. BB5 : Test de personnalité pour Adolescents. 9, 13, 16

Beghetto, Ronald a., and James C Kaufman. 2007. "Toward a broader conception of creativity: A case for "mini-c" creativity." Psychology of Aesthetics, Creativity, and the Arts, 1(2): 73-79. 3

Besançon, Maud, Todd Lubart, and Baptiste Barbot. 2013. "Creative giftedness and educational opportunities." Educational \& Child Psychology, 30(2): 79-88. 2,7

Blavatskyy, PavloR. 2010. "Reverse common ratio effect." Journal of Risk and Uncertainty, 40(3): 219-241. 14

Blickle, Gerhard. 1996. "Personality traits, learning stratigies, and performance." European Journal of Personality, 10(5): 337-352. 19

Bowles, Samuel, and Herbert Gintis. 1975. "The Problem with Human Capital Theory-A Marxian Critique." American Economic Review, 65(2): 74-82. 4

Bowles, Samuel, Herbert Gintis, and Melissa Osborne. 2001. "The Determinants of Earnings: A Behavioral Approach." Journal of Economic Literature, 39(4): 1137-1176. 4

Caprara, Gian Vittorio, Michele Vecchione, Guido Alessandri, Maria Gerbino, and Claudio Barbaranelli. 2011. "The contribution of personality traits and self-efficacy beliefs to academic achievement: a longitudinal study." The British journal of educational psychology, 81: 78-96. 4

Caroff, Xavier, and Todd Lubart. 2012. "Multidimensional Approach to Detecting Creative Potential in Managers." Creativity Research Journal, 24(1): 13-20. 4

Cattell, R.B. 1979. The structure of personality in its environment. New York : Springer Pub Co. 8 
Chamorro-Premuzic, Tomas. 2006. "Creativity versus conscientiousness: Which is a better predictor of student performance?" Applied Cognitive Psychology, 20(4): 521-531. 4

Chamorro-Premuzic, Tomas, and Adrian Furnham. 2003. "Personality predicts academic performance: Evidence from two longitudinal university samples." Journal of Research in Personality, 37(4): 319-338. 4

Cicirelli, Victor G. 1965. "Form of the relationship between creativity, IQ, and academic achievement." Journal of education \& psychology, 56(6): 303-308. 2, 4

Cicirelli, Victor G. 1966. "Sibling constellation, creativity, IQ, and Academic Achievement." Child Development, 38(2): 481-490. 2

Costa Jr, Paul, Antonio Terracciano, and Robert R McCrae. 2001. "Gender differences in personality traits across cultures: robust and surprising findings." Journal of personality and social psychology, 81(2): 322. 20

Cropley, Arthur. 2010. "In praise of convergent thinking." Creativity Research Journal, 18(3): 391-404. 7

Cunha, Flavio, and James Heckman. 2007. "The technology of skill formation." National Bureau of Economic Research. 8, 9

Dee, Thomas S. 2007. "Teachers and the gender gaps in student achievement." Journal of Human Resources, 42(3): 528-554. 20

Didier, Thomas, Clarence D. Kreiter, Russell Buri, and Catherine Solow. 2006. "Investigating the utility of a GPA institutional adjustment index." Advances in Health Sciences Education, 11(2): 145-153. 2

Di Giunta, Laura, Guido Alessandri, Maria Gerbino, Paula Luengo Kanacri, Antonio Zuffiano, and Gian Vittorio Caprara. 2013. "The determinants of scholastic achievement: The contribution of personality traits, self-esteem, and academic self-efficacy." Learning and Individual Differences, 27: 102-108. 4 
Falch, Torberg, and Linn Renée Naper. 2013. "Educational Evaluation Schemes and Gender Gaps in Student Achievement." Economics of Education Review. 20, 24

Feist, Gregory J. 1998. "A meta-analysis of personality in scientific and artistic creativity." Personality and Social Psychology Review, 2(4): 290-309. 4

Feist, Gregory J. 2010. "The function of personality in creativity. The Nature and nurture of the creative personality." In The Cambridge handbook of creativity. , ed. James C. Kaufman and Robert J Sternberg, 113-130. New York:Cambridge University Press. 4

Furnham, Adrian, Jane Zhang, and Tomas Chamorro-Premuzic. 2006. "The relationship between psychometric and self-estimated intelligence, creativity, personality and academic achievement." Imagination, Cognition and Personality, 25(2): $119-145.2$

Getzels, J W, and $\mathbf{P}$ W Jackson. 1962. Creativity and Intelligence. New York:Wiley \& Sons. 4

Goff, Maynard, and Phillip L Ackerman. 1992. "Personality-intelligence relations: Assessment of typical intellectual engagement." Journal of Educational Psychology, 84(4): 537. 19

Guilford, Joy Paul. 1967. The nature of human intelligence. New York:McGrawHill. 7

Guilford, Joy Paul, and Ralph Hoepfner. 1971. The Analysis of Intelligence. New York:McGraw-Hill. 7

Heckman, James J. 2006. "Skill Formation and the Economics of Investing in Disadvantaged Children." Science, 312: 1900-1902. 4 
Heckman, James J., Jora Stixrud, and Sergio Urzua. 2006. "The Effects of Cognitive and Noncognitive Abilities on Labor Market Outcomes and Social Behavior." Journal of Labor Economics, 24(3): 411-482. 4

Holt, Charles, and Susan Laury. 2002. "Risk aversion and incentive effects." American Economic Review, 92: 1644-1655. 6, 10, 13

Hoxby, Caroline. 2000. "Peer Effects in the Classroom: Learning from Gender and Race Variation." National Bureau of Economic Research Working Paper 7867. 15

Jackson, Mark. 2013. "The squeezed middle: An exploration of creativity, conformity and social class on the academic achievement of undergraduate students within a uk art school." International Journal of Art and Design Education, 32(3): 345-351. 2

John, Oliver P., and Sanjay Srivastava. 1999. "The Big Five trait taxonomy: History, measurement, and theoretical perspectives." In Handbook of Personality: Theory and Research. . Second ed., , ed. Lawrence A. Pervin and Oliver P. John, 102-138. New York:Guilford Press. 4

Johnson, V E. 2003. Grade inflation: A crisis in college education. New York:Springer Verlag. 2

Kaufman, James C, and Ronald A Beghetto. 2009. "Beyond big and little: The four c model of creativity." Review of General Psychology, 13(1): 1-12. 3

Kim, K. H., and D. L. Zabelina. 2011. Underachievement. London: Academic Press. 2

Kim, Kyung Hee. 2008. "Meta-Analyses of the Relationship of Creative Achievement to Both IQ and Divergent Thinking Test Scores." The Journal of Creative Behavior, 42(2): 106-130. 7 
Kuncel, Nathan R, Marcus Credé, and Lisa L Thomas. 2005. "The validity of self-reported grade point averages, class Ranks, and test Scores : A meta-Analysis and review of the literature." Review of Educational Research, 75(1): 63-82. 2

Laidra, K., H. Pullmann, and J. Allik. 2007. "Personality and intelligence as predictors of academic achievement: A cross-sectional study from elementary to secondary school." Personality and Individual Differences, 42(3): 441-451. 2

Lavy, Victor. 2008. "Do gender stereotypes reduce girls' or boys' human capital outcomes? Evidence from a natural experiment." Journal of Public Economics, 92(10): 2083-2105. 20, 24

Lévy-Garboua, Louis, Hela Maafi, David Masclet, and Antoine Terracol. 2012. "Risk aversion and framing effects." Experimental Economics, 15(1): 128-144. 14

Loomes, Graham, and Robert Sugden. 1998. "Testing Different Stochastic Specifications of Risky Choice." Economica, 65(260): 581-98. 14

Lubart, Todd. 2001. "Models of the Creative Process: Past, Present and Future." Creativity Research Journal, 13(3-4): 295-308. 7

Lubart, Todd, and Christophe Mouchiroud. 2003. "Creativity: A Source of Difficulty in Problem Solving." In The Psychology of Problem Solving., ed. Janet E. Davidson and Robert J Sternberg, 127-148. Cambridge:Cambridge University Press. 8

Lubart, Todd, and Jacques-Henri Guignard. 2004. "The generality-specificity of creativity: a multivariate approach." In Creativity: From Potential to Realization. , ed. Robert J Sternberg, Elena L Grigorenko and Jerome L Singer, 43-56. Washington, D.C.:American Psychological Association. 7

Lubart, Todd, Maud Besançon, and Baptiste Barbot. 2011. Evaluation du Potentiel Créatif (EPoC). Paris:Hogrefe. 9, 10, 11, 12 
Maehr, Martin L., and Carol Midgley. 1991. "Enhancing student motivation: A schoolwide approach." Educational Psychologist, 26(3-4): 399-427. 20

Majaro, Simon. 1992. "Strategy search and creativity: The key to corporate renewal." European management journal, 10(2): 230-238. 3

Markman, Jacob M., Eric A. Hanushek, John F. Kain, and Steven G. Rivkin. 2003. "Does peer ability affect student achievement?" Journal of Applied Econometrics, 18(5): 527-544. 15

McCrae, Robert R, and Paul T Costa. 1987. "Validation of the five-factor model of personality across instruments and observers." Journal of personality and social psychology, 52(1): 81. 4, 5, 12, 17

Meece, Judith L., Beverly Bower Glienke, and Samantha Burg. 2006. "Gender and motivation." Journal of School Psychology, 44(5): 351-373. 20

Nami, Yaghoob, Hossein Marsooli, and Maral Ashouri. 2014. "The Relationship between Creativity and Academic Achievement." Procedia - Social and Behavioral Sciences, 114: 36-39. 2

Ouazad, Amine, and Lionel Page. 2013. "Students' perceptions of teacher biases: Experimental economics in schools." Journal of Public Economics, 105(0): 116 130. 21

Poropat, Arthur E. 2009. "A meta-analysis of the five-factor model of personality and academic performance." Psychological bulletin, 135(2): 322-38. 4

Rhodes, Mel. 1961. "An analysis of creativity." The Phi Delta Kappa, 42(7): 205210. 4

Richardson, Michelle, Charles Abraham, and Rod Bond. 2012. "Psychological correlates of university students' academic performance: a systematic review and meta-analysis." Psychological bulletin, 138(2): 353-87. 2, 4 
Richards, Ruth. 1999. "Everyday Creativity." In Encyclopedia of Creativity. Vol 1. , ed. Mark A Runco and Steven R Pritzker, 683-687. London:Academic Press. 3

Richards, Ruth. 2010. "Everyday creativity." The Cambridge handbook of creativity, 189ff. 3

Rubinstein, Gidi. 2005. "The big five among male and female students of different faculties." Personality and Individual Differences, 38(7): 1495-1503. 20

Runco, Mark a. 2004. "Creativity." Annual review of psychology, 55: 657-87. 3, 7

Runco, Mark A. 2007. "A hierarchical framework for the study of creativity." New Horizons in Education, 55(3): 1-9. 4

Runco, Mark A, and D Kim. 2011. "The four ps of creativity: person, product, process, and press." In Encyclopedia of Creativity. , ed. Mark A Runco and Steven R Pritzker, 534-537. San Diego:Academic Press. 4, 7

Runco, Mark A, and Garrett J. Jaeger. 2012. "The Standard Definition of Creativity." Creativity Research Journal, 24(1): 92-96. 3

Sen, Arun K, and Knuta Hagtvet. 1993. "Correlations among creativity, intelligence, personality, and academic achievement." Perceptual and Motor Skills, $77(2): 497-498.2$

Steinmayr, Ricarda, and Birgit Spinath. 2008. "Sex differences in school achievement: what are the roles of personality and achievement motivation?" European Journal of Personality, 22(3): 185-209. 2

Sternberg, Robert J, and Todd Lubart. 1995. Defying the crowd: Cultivating creativity in a culture of conformity. New York:Free Press. 2, 3

Sternberg, Robert J, and Todd Lubart. 1999. "The Concept of Creativity: Prospects and Paradigms." In Handbook of Creativity. , ed. Robert J Sternberg, 3-15. Cambridge:Cambridge University Press. 3 
Torrance, E. P. 1962. Guiding Creative Talent. Englewood Cliffs, NJ:Prentice-Hall. $4,10,11$

Van Klaveren, Chris. 2011. "Lecturing style teaching and student performance." Economics of Education Review, 30(4): 729-739. 8

Weiss, Andrew. 1995. "Human capital vs. signalling explanations of wages." The Journal of Economic Perspectives, 9(4): 133-154. 2

Yamamoto, Kaoru. 1964. "Threshold of intelligence in academic achievement of highly creative students." The Journal of Experimental Education, 32(4): 401-405. 4

Yeh, Yu-Chu. 2004. "Seventh graders ÁçấňâĎć academic achievement, creativity, and ability to construct a cross-domain Concept Map ÁçấňâĂİ A Brain Function Perspective." The Journal of Creative Behavior, 38(2): 125-144. 2

Zeng, Liang, Robert W. Proctor, and Gavriel Salvendy. 2011. "Can traditional divergent thinking tests be trusted in measuring and predicting real-world creativity?" Creativity Research Journal, 23(1): 24-37. 4

Zuckerman, Marvin, and Bernard Lubin. 1965. Multiple affect adjective check list. EdITS/Educational and Industrial Testing Service. 10

Zuffianò, Antonio, Guido Alessandri, Maria Gerbino, Bernadette Paula Luengo Kanacri, Laura Di Giunta, Michela Milioni, and Gian Vittorio Caprara. 2013. "Academic achievement: The unique contribution of self-efficacy beliefs in self-regulated learning beyond intelligence, personality traits, and selfesteem." Learning and Individual Differences, 23(1): 158-162. 4 


\section{Figures and tables}

\section{Figures}
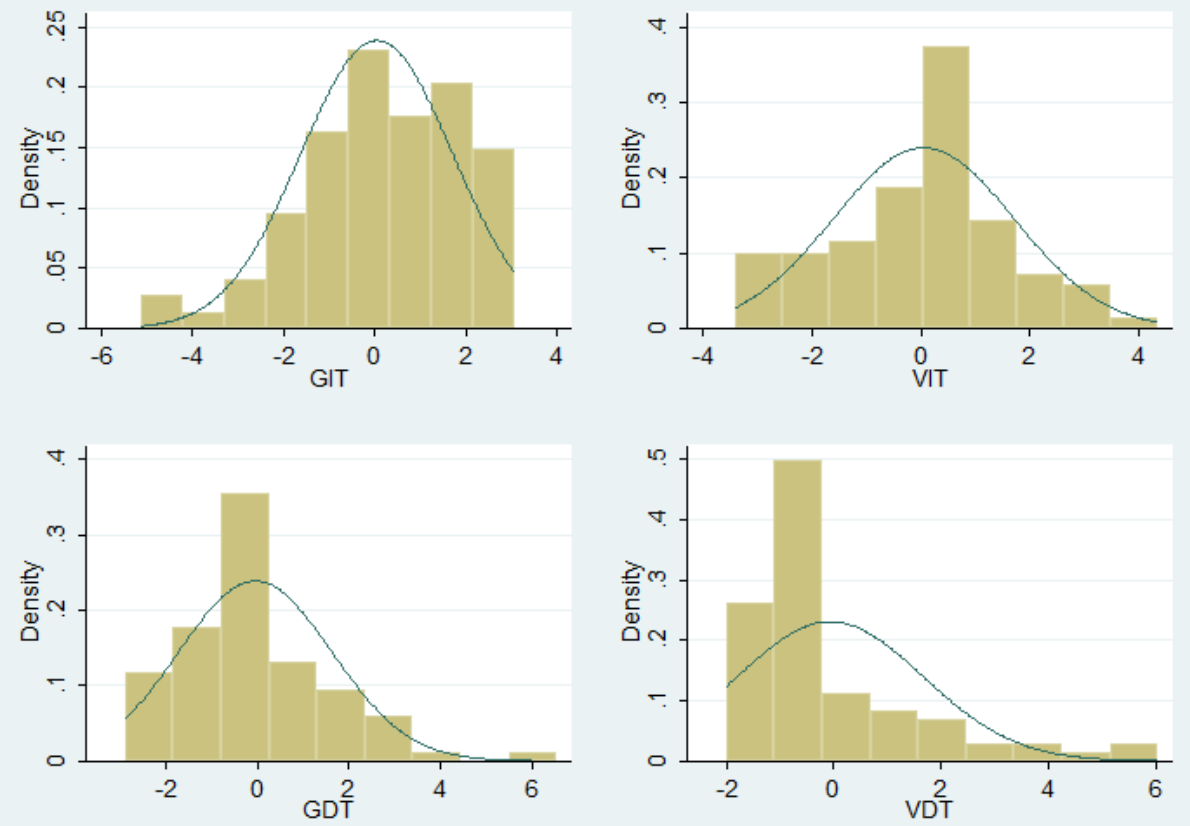

Figure 1: Distribution of the four standardized creativity scores 

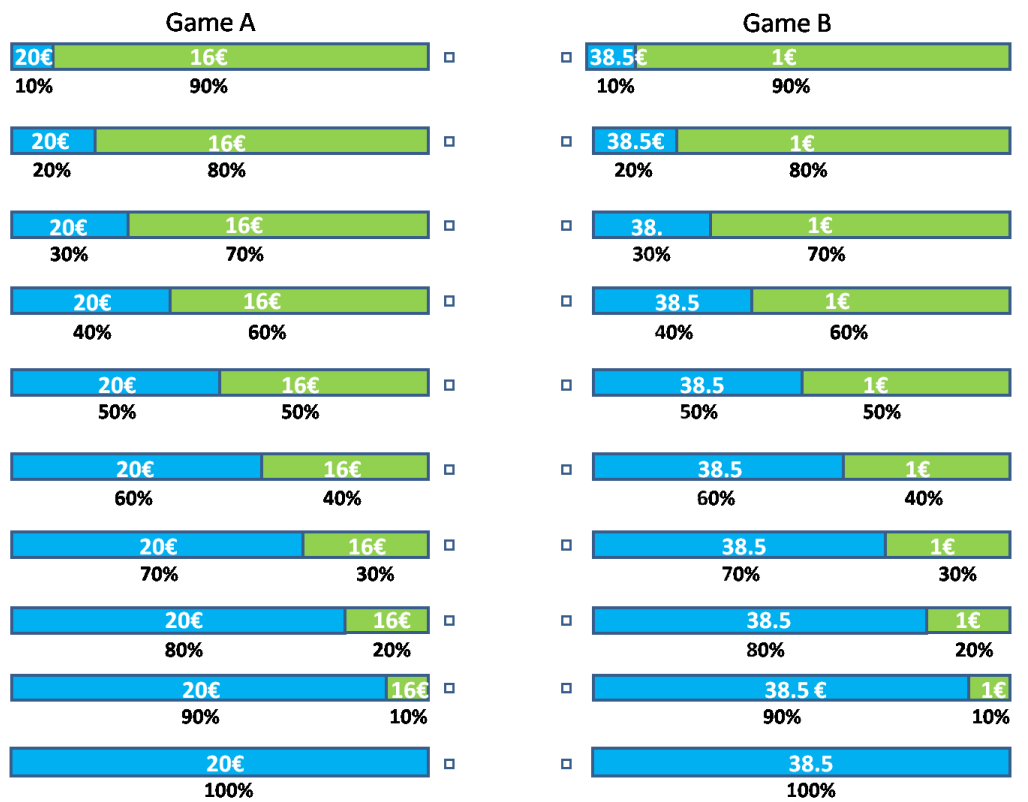

ㅁ \begin{tabular}{r}
\hline 8.5 \\
$100 \%$
\end{tabular}

Figure 2: Lottery choices

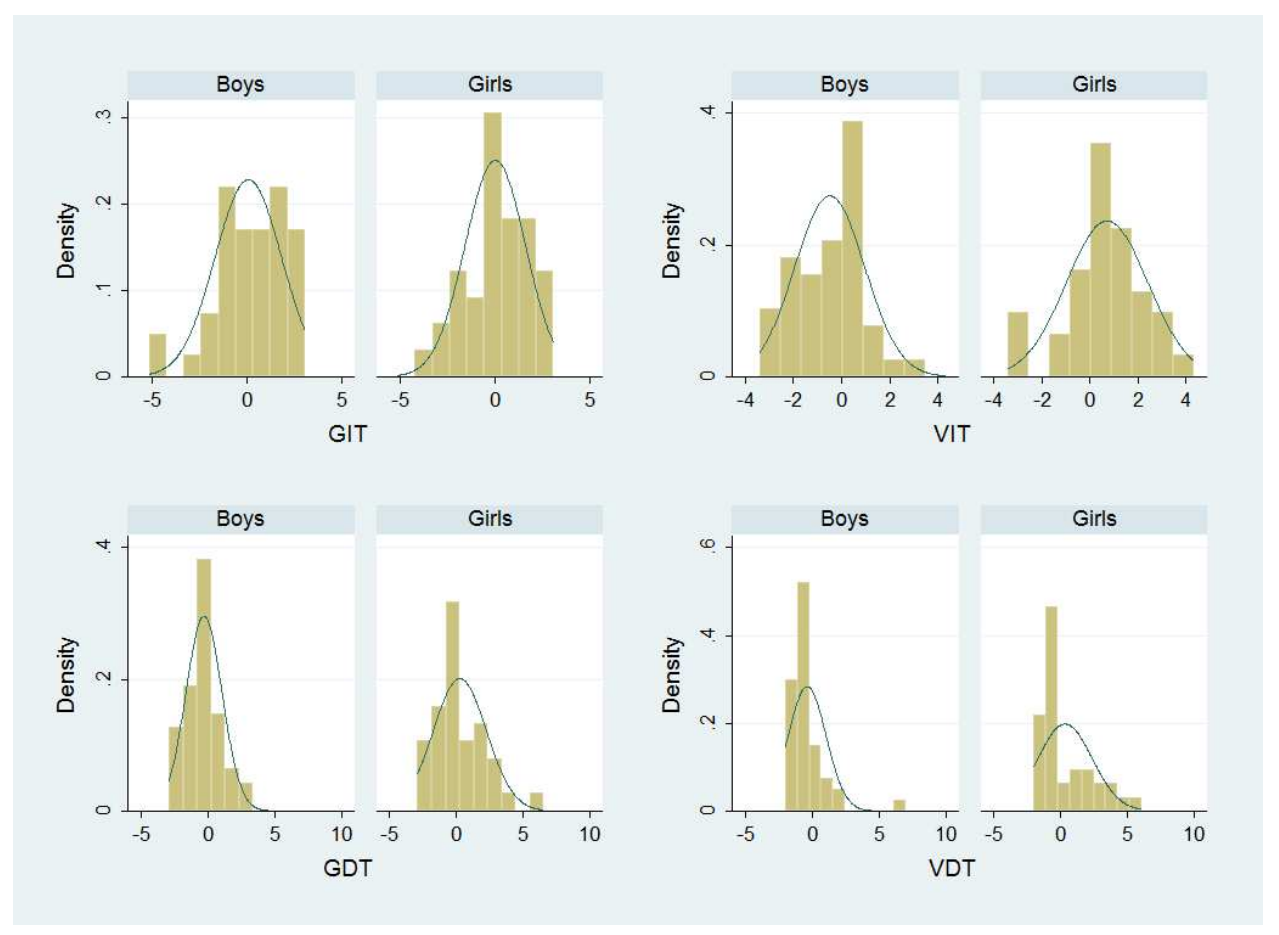

Figure 3: Creativity scores by gender

\section{Tables}




\begin{tabular}{c|l|c}
\hline \hline Category & Course & N \\
\hline \multirow{3}{*}{ Sciences } & Mathematics & 97 \\
& Physics and Chemistry & 95 \\
& Biology & 92 \\
\hline \multirow{4}{*}{ Humanities } & French & 97 \\
& Foreign language (FL) & 96 \\
& History and Geography & 97 \\
\hline \multirow{4}{*}{ Secondary } & Arts & 69 \\
& Music & 83 \\
& IT & 96 \\
& Physic Education (PE) & 90 \\
\hline \hline
\end{tabular}

Table 1: Mandatory subjects a middle school pupil studies and number of observations for each subject

\begin{tabular}{l|llll}
\hline \hline & GIT & VIT & GDT & VDT \\
\hline Agreeableness & 0.2910 & $0.2540^{* *}$ & 0.1023 & $0.2003^{*}$ \\
& $(0.0113)$ & $(0.028)$ & $(0.383)$ & $(0.085)$ \\
Conscientiousness & 0.0129 & 0.1431 & -0.0436 & -0.0118 \\
& $(0.912)$ & $(0.221)$ & $(0.710)$ & $(0.920)$ \\
Extraversion & -0.0084 & 0.1821 & 0.0991 & $0.2532^{* * *}$ \\
Emotional stability & $(0.943)$ & $(0.118)$ & $(0.397)$ & $(0.028)$ \\
& & & & \\
Openness & -0.1520 & $-0.2052^{*}$ & -0.1328 & -0.1506 \\
& $(0.193)$ & $(0.077)$ & $(0.256)$ & $(0.197)$ \\
& $0.2050^{*}$ & $0.3338^{* * *}$ & 0.1161 & $0.3225^{* * *}$ \\
& $(0.078)$ & $(0.003)$ & $(0.321)$ & $(0.005)$ \\
\hline \hline
\end{tabular}

Table 2: Correlation between the BB5 personality traits and the creativity scores ( $\mathrm{p}$-values in parentheses, ${ }^{* * *} \mathrm{p}<0.01,{ }^{* *} \mathrm{p}<0.05,{ }^{*} \mathrm{p}<0.1$ ). 


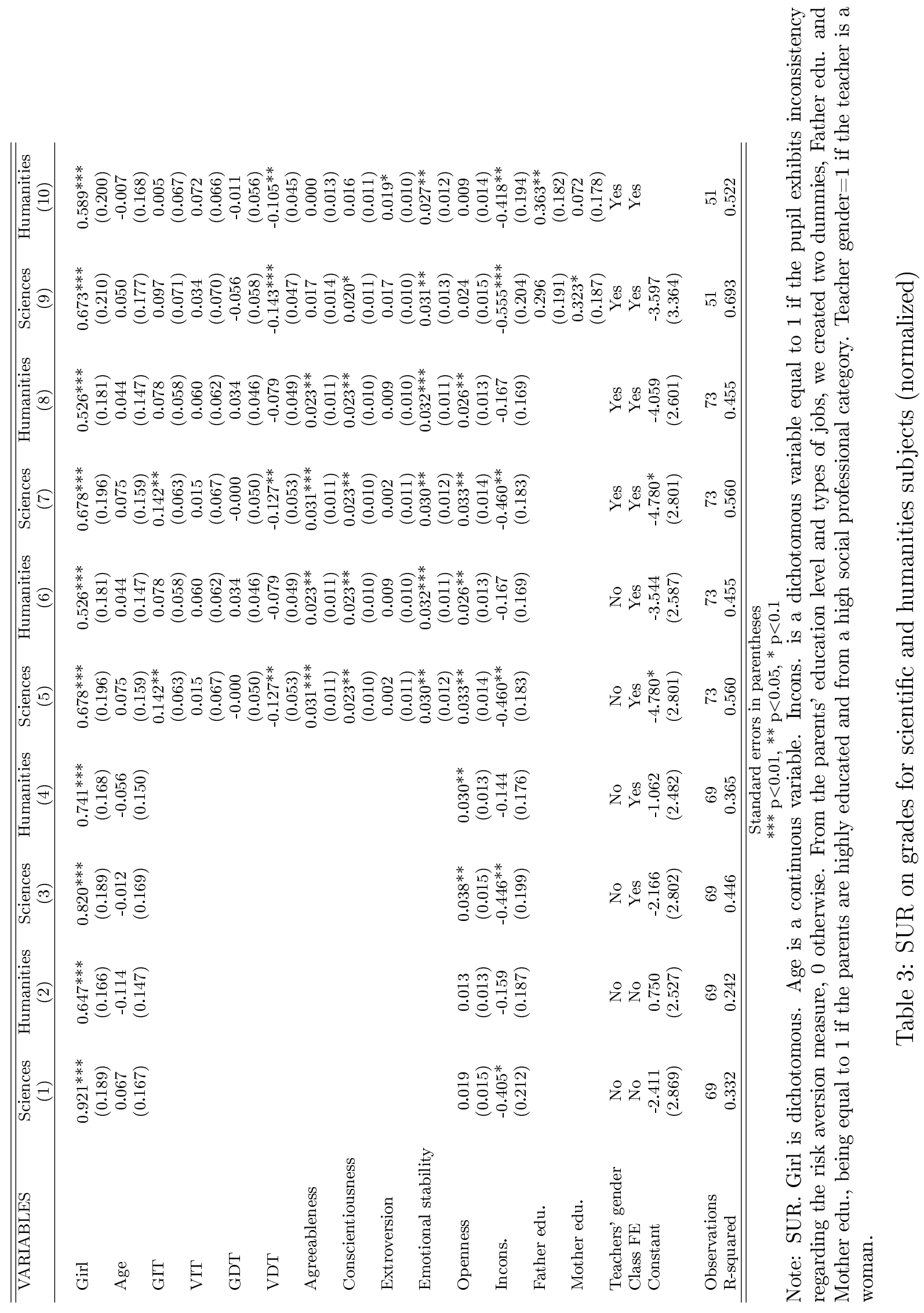




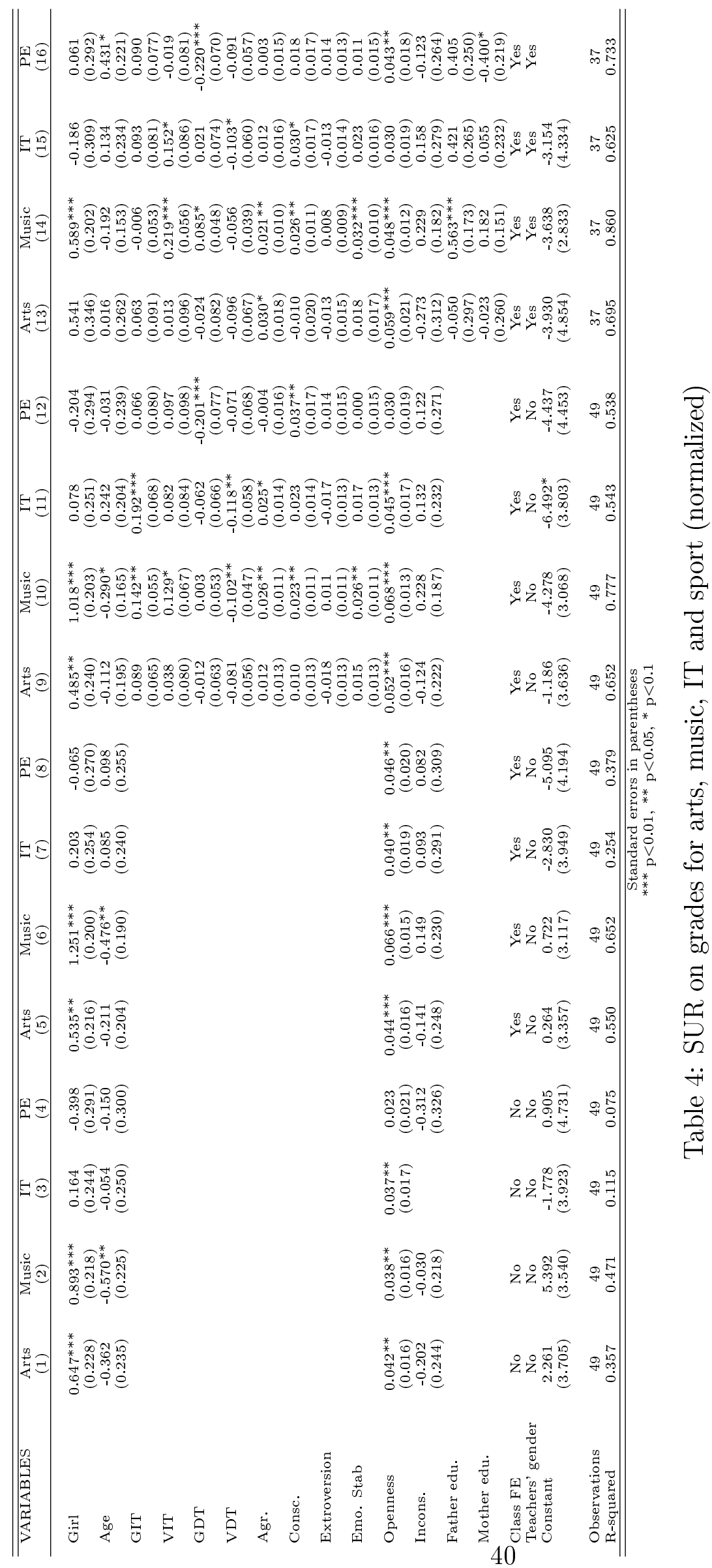




\begin{tabular}{|c|c|c|c|}
\hline VARIABLES & $\begin{array}{c}\text { Passed } \\
\text { (1) }\end{array}$ & $\begin{array}{c}\text { Passed } \\
(2)\end{array}$ & $\begin{array}{c}\text { Passed } \\
\text { (3) }\end{array}$ \\
\hline Girl $=1$ & $\begin{array}{l}-0.122 \\
(0.087)\end{array}$ & $\begin{array}{c}-0.181^{* * *} \\
(0.054)\end{array}$ & $\begin{array}{c}-0.129^{*} \\
(0.074)\end{array}$ \\
\hline Age $>14$ years & $\begin{array}{c}-0.461^{* * * *} \\
(0.103)\end{array}$ & $\begin{array}{c}-0.282^{* * * *} \\
(0.067)\end{array}$ & $\begin{array}{c}-0.162^{* * *} \\
(0.062)\end{array}$ \\
\hline Sciences test scores 9 th gr. & $\begin{array}{c}0.140^{* *} \\
(0.067)\end{array}$ & $\begin{array}{l}0.121^{* *} \\
(0.061)\end{array}$ & $\begin{array}{c}0.119^{* * *} \\
(0.034)\end{array}$ \\
\hline Humanities test scores 9th gr. & $\begin{array}{c}0.050 \\
(0.071)\end{array}$ & $\begin{array}{c}0.042 \\
(0.058)\end{array}$ & $\begin{array}{c}0.005 \\
(0.043)\end{array}$ \\
\hline Agreeableness & & $\begin{array}{c}0.011^{* * *} \\
(0.004)\end{array}$ & \\
\hline Conscientiousness & & $\begin{array}{l}-0.000 \\
(0.004)\end{array}$ & \\
\hline Extroversion & & $\begin{array}{c}0.000 \\
(0.005)\end{array}$ & \\
\hline Emotional Stability & & $\begin{array}{c}0.010^{*} \\
(0.005)\end{array}$ & \\
\hline Openness & & $\begin{array}{c}0.026^{* * *} \\
(0.007)\end{array}$ & \\
\hline GIT & & & $\begin{array}{c}0.050^{* * *} \\
(0.018)\end{array}$ \\
\hline VIT & & & $\begin{array}{c}0.077^{* * *} \\
(0.017)\end{array}$ \\
\hline GDT & & & $\begin{array}{l}-0.026 \\
(0.016)\end{array}$ \\
\hline VDT & & & $\begin{array}{c}0.021 \\
(0.021)\end{array}$ \\
\hline Observations & 75 & 73 & 75 \\
\hline
\end{tabular}

Standard errors in parentheses

*** $\mathrm{p}<0.01,{ }^{* *} \mathrm{p}<0.05,{ }^{*} \mathrm{p}<0.1$

Table 5: Marginal probability effect on passing the final exam

\section{Appendix}




\begin{tabular}{l|cc|c}
\hline \hline & Girls & Boys & T-test p-value \\
\hline Agreeableness & 67.7 & 62.4 & 0.00 \\
Conscientiousness & 64.4 & 60.9 & 0.09 \\
Extraversion & 64.3 & 62.5 & 0.34 \\
Emotional Stability & 64.5 & 64.4 & 0.99 \\
Openness & 62.7 & 59.4 & 0.04 \\
& $\mathrm{n}=42$ & $\mathrm{n}=49$ & \\
\hline \hline
\end{tabular}

Table 6: BB5 scores by gender

champs
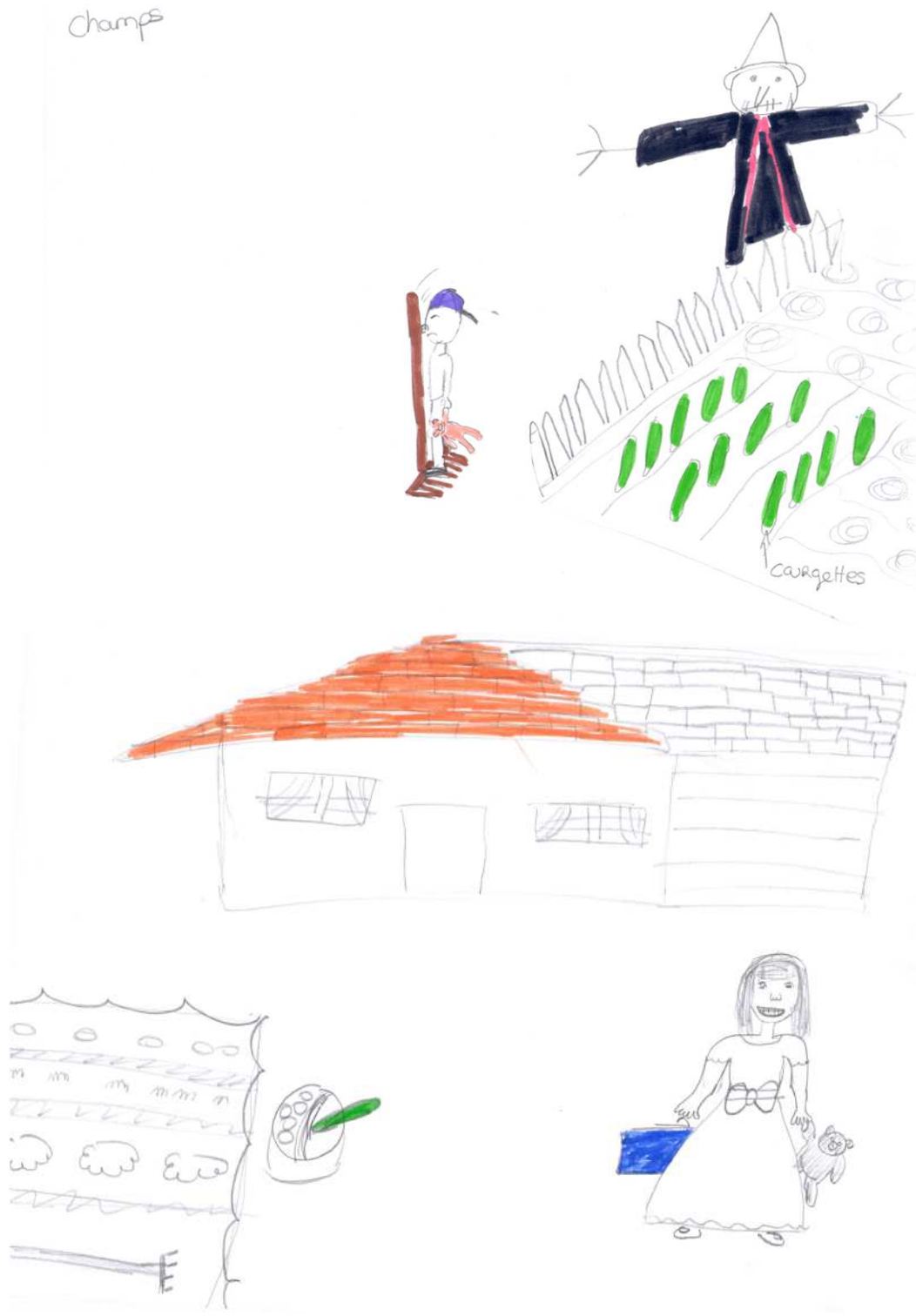

Figure 4: Two examples of the GIT task. 


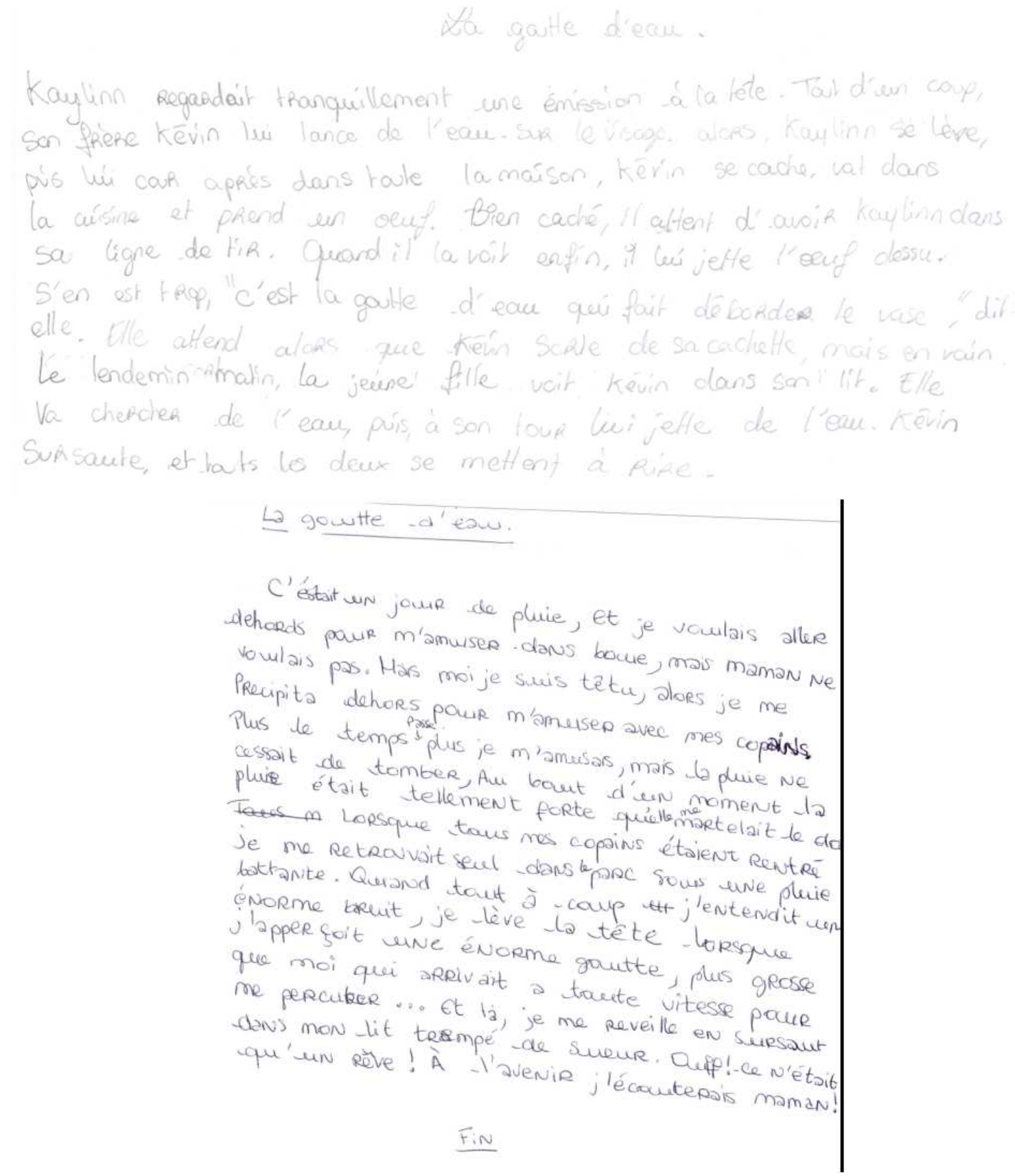

Figure 5: Two examples of the VIT task: writing a story based on the title "Drop of Water" 


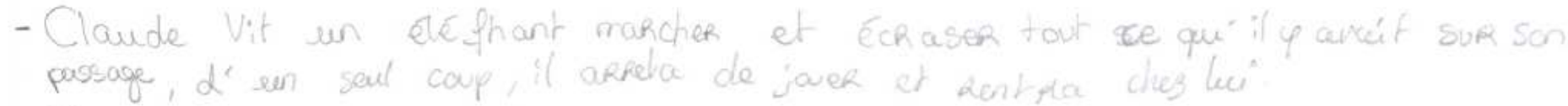

- Claude vit un immauble s'éfondrer - Claude vit que ce bruir n'e etciit que celui d'une jeune fille ne sachant pr

- Claude vit un hacheur Rouler pás du pare

- Il tarina sa tele, et vit le sol fissuné

- Claude rieut pas le temps de tourner la tele, qui il écát poursus.

-Claude Rentra chez lui

- Más il contrinua ájoved sans s'en occuper

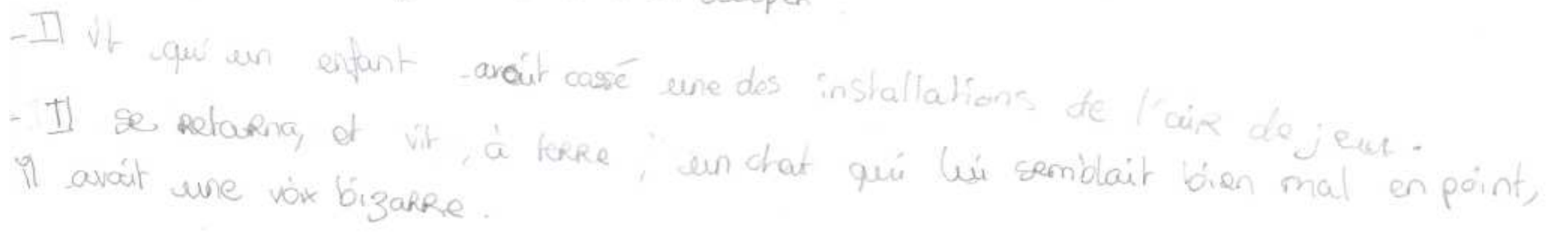
In apris Claude jourait am Barc Loresque il entend un bRuit..

(1) Il se precicipita apperer derière un buisson, il n'ossit mềnéto pa

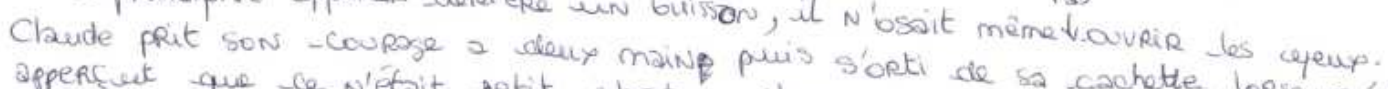

(2) appençut que de n'était petit. chaton, il se senti rudicule.

Claude trés curieup s'emprassa d'aller voie

bruit se déplacait de plus en plus vite. Clarde qu' it se passait, mais le

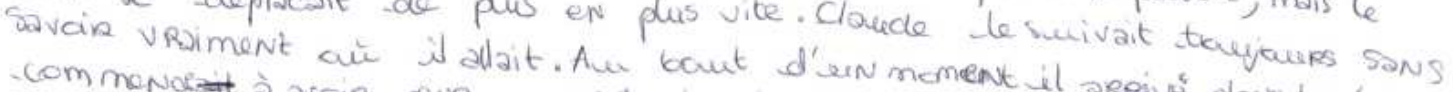
des buisson. Mavir peur quand taut a g coup 3 jeunes el ans les toís et (3) une farce. Mais ce N'était rien, juste-ses amis quí vourait huifon

Figure 6: Two examples of the VDT task: writing as many ends of a story as possible 


\begin{tabular}{|c|c|c|c|c|c|}
\hline $\mid \frac{\not}{\sigma}$ & 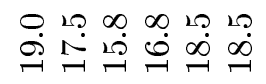 & 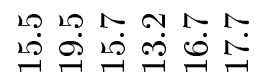 & 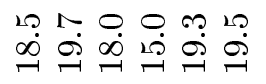 & 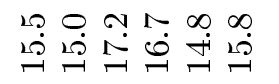 & 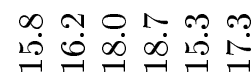 \\
\hline$\exists$ & ڤִ & 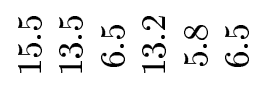 & 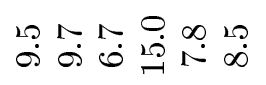 & 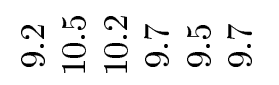 & 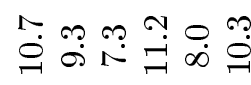 \\
\hline & 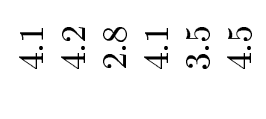 & 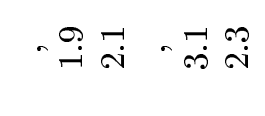 & 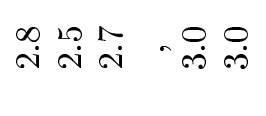 & 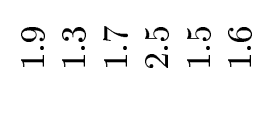 & 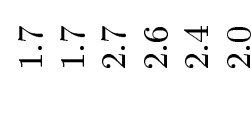 \\
\hline 胥 & 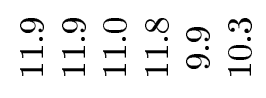 & 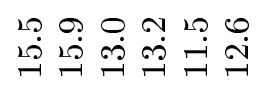 & 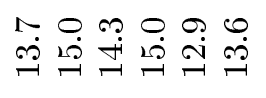 & 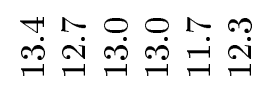 & 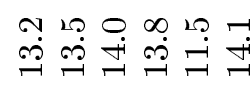 \\
\hline$\therefore$ & $\stackrel{\infty}{\sim} \stackrel{\oplus}{\sim} \stackrel{\sim}{\sim} \stackrel{0}{\sim}$ & $\neg \bumpeq \stackrel{20}{\sim}-\odot \stackrel{\sim}{\sim}$ & 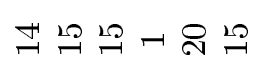 & 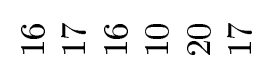 & $\stackrel{\oplus}{\oplus} \oplus \infty \stackrel{\infty}{=}$ \\
\hline$\frac{0}{0}$ & 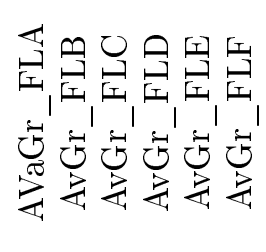 & 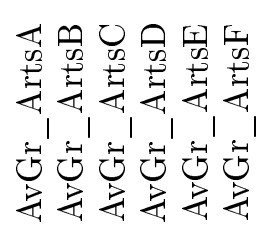 & 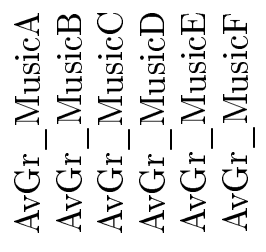 & 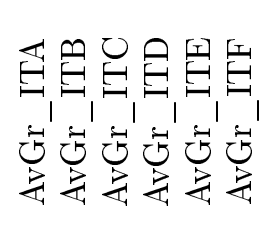 & 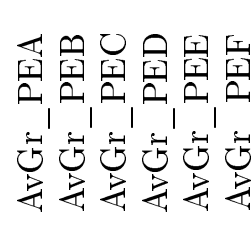 \\
\hline 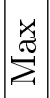 & 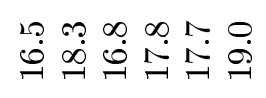 & 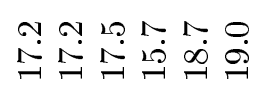 & 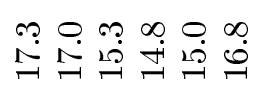 & 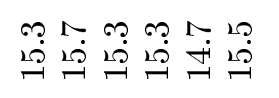 & 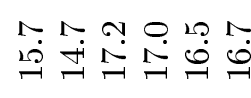 \\
\hline$\Xi$ & 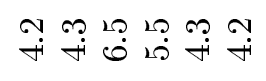 & 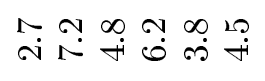 & 華 & 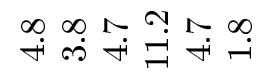 & 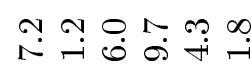 \\
\hline$\stackrel{\varrho}{\oplus}$ & 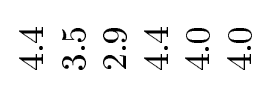 & 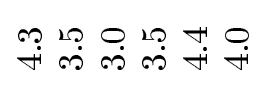 & ڤִ & 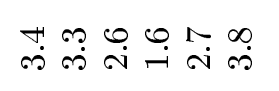 & 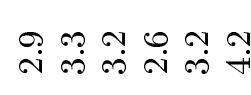 \\
\hline 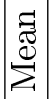 & 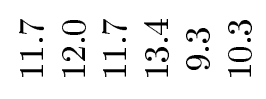 & 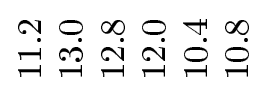 & 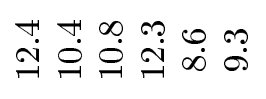 & 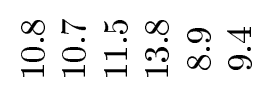 & 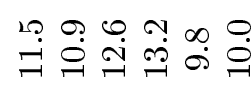 \\
\hline$\frac{0}{0}$ & 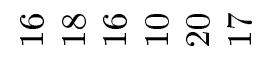 & 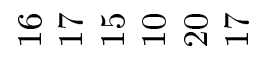 & $\stackrel{20}{\rightarrow} \stackrel{\infty}{\sim} 0 \bigcirc$ & 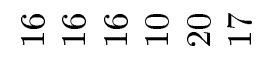 & 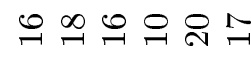 \\
\hline$\because \ddot{\bar{\sigma}}$ & 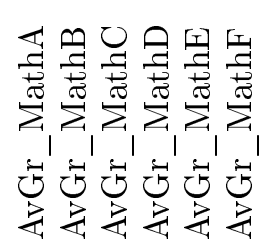 & 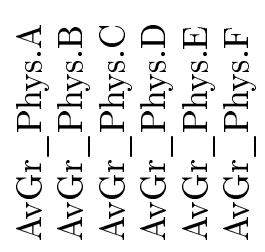 & 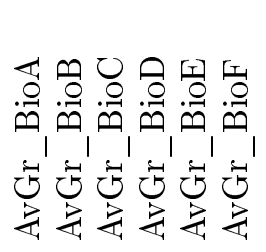 & 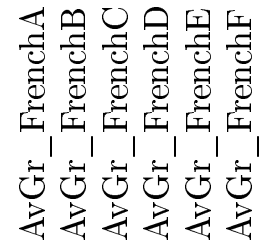 & 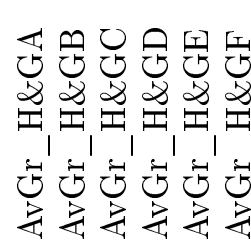 \\
\hline
\end{tabular}




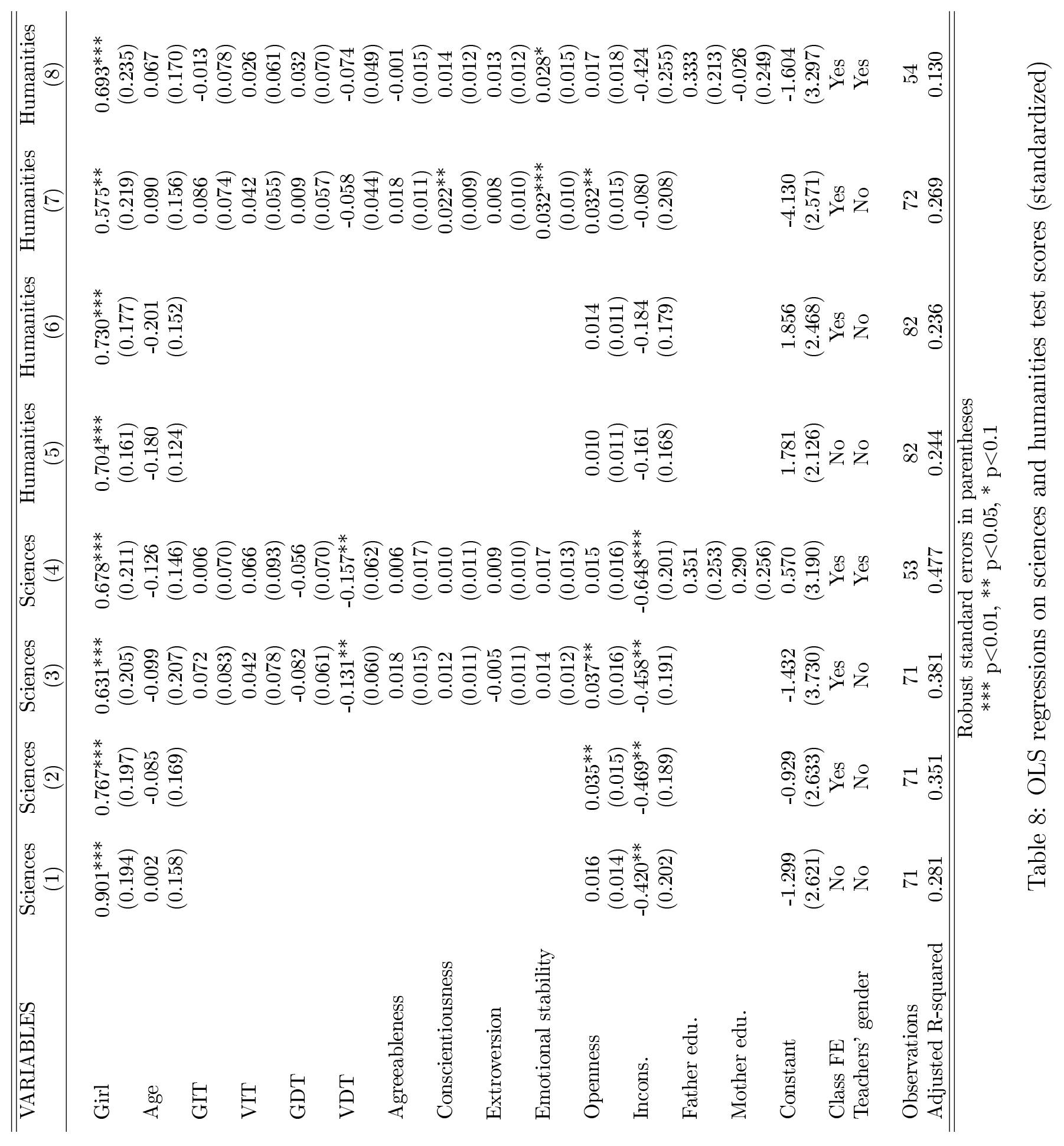



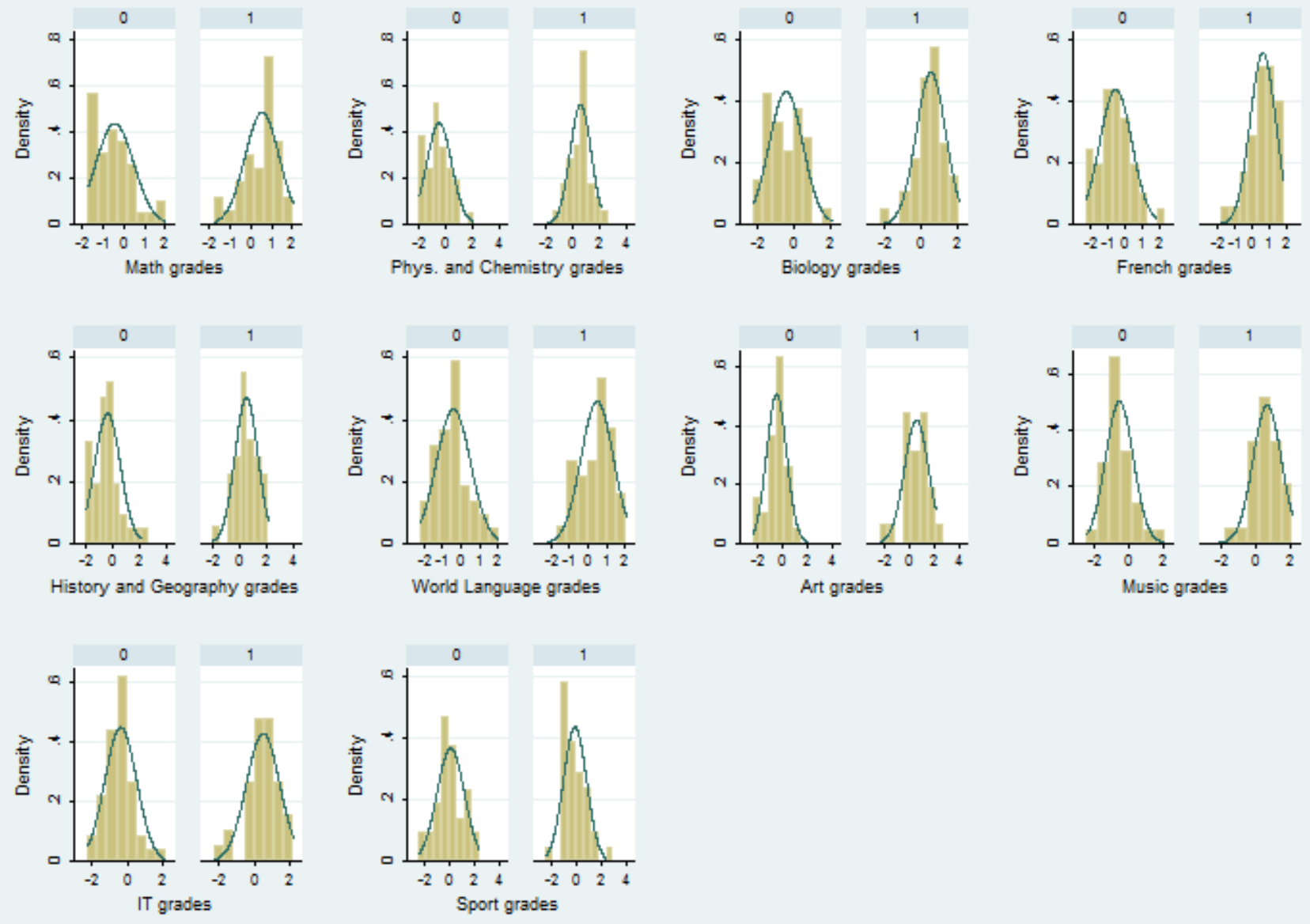

Figure 7: Distribution of standardized grades per subject, by gender ( $O$ for boys, 1 for girls) 


\begin{tabular}{|c|c|c|c|c|c|c|c|c|}
\hline VARIABLES & $\begin{array}{l}\text { Arts } \\
(1)\end{array}$ & $\begin{array}{l}\text { Arts } \\
(2)\end{array}$ & $\begin{array}{l}\text { Arts } \\
(3)\end{array}$ & $\begin{array}{c}\text { Arts } \\
(4)\end{array}$ & $\begin{array}{c}\text { Music } \\
(5)\end{array}$ & $\begin{array}{c}\text { Music } \\
(6)\end{array}$ & $\begin{array}{c}\text { Music } \\
(7)\end{array}$ & $\begin{array}{c}\text { Music } \\
(8)\end{array}$ \\
\hline Girl & $\begin{array}{c}0.540^{* *} \\
(0.246)\end{array}$ & $\begin{array}{l}0.434^{*} \\
(0.232)\end{array}$ & $\begin{array}{c}0.441^{* *} \\
(0.203)\end{array}$ & $\begin{array}{c}0.550 \\
(0.456)\end{array}$ & $\begin{array}{c}1.062^{* * *} \\
(0.212)\end{array}$ & $\begin{array}{c}1.247^{* * *} \\
(0.210)\end{array}$ & $\begin{array}{c}0.943^{* * * *} \\
(0.270)\end{array}$ & $\begin{array}{c}0.617^{* *} \\
(0.296)\end{array}$ \\
\hline Age & $\begin{array}{c}-0.475^{* *} \\
(0.208)\end{array}$ & $\begin{array}{l}-0.272 \\
(0.171)\end{array}$ & $\begin{array}{l}-0.262 \\
(0.156)\end{array}$ & $\begin{array}{l}-0.174 \\
(0.235)\end{array}$ & $\begin{array}{l}-0.358 \\
(0.221)\end{array}$ & $\begin{array}{l}-0.298 \\
(0.180)\end{array}$ & $\begin{array}{l}-0.078 \\
(0.208)\end{array}$ & $\begin{array}{c}0.166 \\
(0.232)\end{array}$ \\
\hline GIT & & & $\begin{array}{c}0.022 \\
(0.051)\end{array}$ & $\begin{array}{l}-0.039 \\
(0.076)\end{array}$ & & & $\begin{array}{c}0.121^{*} \\
(0.069)\end{array}$ & $\begin{array}{l}-0.004 \\
(0.059)\end{array}$ \\
\hline VIT & & & $\begin{array}{c}0.037 \\
(0.085)\end{array}$ & $\begin{array}{c}0.021 \\
(0.107)\end{array}$ & & & $\begin{array}{c}0.110 \\
(0.083)\end{array}$ & $\begin{array}{c}0.212^{* *} \\
(0.088)\end{array}$ \\
\hline GDT & & & $\begin{array}{c}-0.020 \\
(0.061)\end{array}$ & $\begin{array}{l}-0.030 \\
(0.089)\end{array}$ & & & $\begin{array}{l}-0.018 \\
(0.078)\end{array}$ & $\begin{array}{c}0.079 \\
(0.068)\end{array}$ \\
\hline VDT & & & $\begin{array}{l}-0.086 \\
(0.091)\end{array}$ & $\begin{array}{l}-0.102 \\
(0.127)\end{array}$ & & & $\begin{array}{l}-0.042 \\
(0.049)\end{array}$ & $\begin{array}{c}0.000 \\
(0.045)\end{array}$ \\
\hline Agreeableness & & & $\begin{array}{l}-0.003 \\
(0.012)\end{array}$ & $\begin{array}{c}0.015 \\
(0.019)\end{array}$ & & & $\begin{array}{c}0.017 \\
(0.017)\end{array}$ & $\begin{array}{c}0.021 \\
(0.020)\end{array}$ \\
\hline Conscientiousness & & & $\begin{array}{c}0.007 \\
(0.014)\end{array}$ & $\begin{array}{l}-0.022 \\
(0.028)\end{array}$ & & & $\begin{array}{c}0.035^{* * *} \\
(0.012)\end{array}$ & $\begin{array}{c}0.039^{* * *} \\
(0.013)\end{array}$ \\
\hline Extroversion & & & $\begin{array}{l}-0.027 \\
(0.017)\end{array}$ & $\begin{array}{l}-0.026 \\
(0.021)\end{array}$ & & & $\begin{array}{c}0.001 \\
(0.011)\end{array}$ & $\begin{array}{c}0.012 \\
(0.010)\end{array}$ \\
\hline Emotional stability & & & $\begin{array}{c}0.007 \\
(0.018)\end{array}$ & $\begin{array}{c}0.003 \\
(0.022)\end{array}$ & & & $\begin{array}{c}0.032^{* *} \\
(0.014)\end{array}$ & $\begin{array}{c}0.044^{* * *} \\
(0.015)\end{array}$ \\
\hline Openness & $\begin{array}{c}0.029 * \\
(0.016)\end{array}$ & $\begin{array}{l}0.032^{*} \\
(0.017)\end{array}$ & $\begin{array}{c}0.042^{* *} \\
(0.018)\end{array}$ & $\begin{array}{l}0.046^{*} \\
(0.025)\end{array}$ & $\begin{array}{c}0.040^{* * *} \\
(0.014)\end{array}$ & $\begin{array}{c}0.055^{* * *} \\
(0.015)\end{array}$ & $\begin{array}{c}0.062 * * * \\
(0.016)\end{array}$ & $\begin{array}{c}0.052^{* * *} \\
(0.015)\end{array}$ \\
\hline Incons. & $\begin{array}{l}-0.241 \\
(0.354)\end{array}$ & $\begin{array}{l}-0.205 \\
(0.266)\end{array}$ & $\begin{array}{l}-0.193 \\
(0.240)\end{array}$ & $\begin{array}{l}-0.452 \\
(0.406)\end{array}$ & $\begin{array}{l}-0.136 \\
(0.202)\end{array}$ & $\begin{array}{l}-0.013 \\
(0.224)\end{array}$ & $\begin{array}{c}0.140 \\
(0.201)\end{array}$ & $\begin{array}{c}0.036 \\
(0.184)\end{array}$ \\
\hline Father edu. & & & & $\begin{array}{l}-0.018 \\
(0.414)\end{array}$ & & & & $\begin{array}{c}0.745^{* * *} \\
(0.267)\end{array}$ \\
\hline Mother edu. & & & & $\begin{array}{l}-0.075 \\
(0.303)\end{array}$ & & & & $\begin{array}{c}0.053 \\
(0.226)\end{array}$ \\
\hline Constant & $\begin{array}{c}4.801 \\
(3.276)\end{array}$ & $\begin{array}{c}2.008 \\
(2.963)\end{array}$ & $\begin{array}{c}3.307 \\
(2.593)\end{array}$ & $\begin{array}{c}1.548 \\
(4.463)\end{array}$ & $\begin{array}{c}2.187 \\
(3.272)\end{array}$ & $\begin{array}{c}0.149 \\
(2.649)\end{array}$ & $\begin{array}{l}-4.694 \\
(3.095)\end{array}$ & $\begin{array}{l}-8.350^{*} \\
(4.159)\end{array}$ \\
\hline Class FE & No & Yes & Yes & Yes & No & Yes & Yes & Yes \\
\hline Teachers' Gender & No & No & No & Yes & No & No & No & Yes \\
\hline Observations & 53 & 53 & 53 & 40 & 60 & 60 & 60 & 47 \\
\hline Adjusted R-squared & 0.219 & 0.455 & 0.467 & 0.379 & 0.455 & 0.502 & 0.575 & 0.623 \\
\hline
\end{tabular}

Robust standard errors in parentheses

${ }^{* * *} \mathrm{p}<0.01,{ }^{* *} \mathrm{p}<0.05,{ }^{*} \mathrm{p}<0.1$

Table 9: OLS regressions on arts and music scores (standardized) 


\begin{tabular}{|c|c|c|c|c|c|c|c|c|}
\hline VARIABLES & $\begin{array}{l}\text { IT } \\
(1)\end{array}$ & $\begin{array}{l}\text { IT } \\
(2)\end{array}$ & $\begin{array}{l}\text { IT } \\
(3)\end{array}$ & $\begin{array}{l}\text { IT } \\
(4)\end{array}$ & $\begin{array}{l}\mathrm{PE} \\
(5)\end{array}$ & $\begin{array}{l}\mathrm{PE} \\
(6)\end{array}$ & $\begin{array}{l}\mathrm{PE} \\
(7)\end{array}$ & $\begin{array}{l}\mathrm{PE} \\
(8)\end{array}$ \\
\hline Girl & $\begin{array}{l}0.434^{*} \\
(0.226)\end{array}$ & $\begin{array}{c}0.267 \\
(0.222)\end{array}$ & $\begin{array}{c}0.169 \\
(0.278)\end{array}$ & $\begin{array}{c}0.195 \\
(0.323)\end{array}$ & $\begin{array}{c}-0.439 * \\
(0.232)\end{array}$ & $\begin{array}{l}-0.354 \\
(0.226)\end{array}$ & $\begin{array}{c}-0.551^{* *} \\
(0.253)\end{array}$ & $\begin{array}{c}-0.551^{*} \\
(0.324)\end{array}$ \\
\hline Age & $\begin{array}{c}0.033 \\
(0.155)\end{array}$ & $\begin{array}{c}0.005 \\
(0.148)\end{array}$ & $\begin{array}{c}0.082 \\
(0.159)\end{array}$ & $\begin{array}{c}0.096 \\
(0.176)\end{array}$ & $\begin{array}{c}0.114 \\
(0.189)\end{array}$ & $\begin{array}{c}0.128 \\
(0.208)\end{array}$ & $\begin{array}{c}0.172 \\
(0.201)\end{array}$ & $\begin{array}{c}0.134 \\
(0.158)\end{array}$ \\
\hline GIT & & & $\begin{array}{l}0.120^{*} \\
(0.068)\end{array}$ & $\begin{array}{c}0.095 \\
(0.075)\end{array}$ & & & $\begin{array}{c}0.023 \\
(0.077)\end{array}$ & $\begin{array}{c}0.047 \\
(0.086)\end{array}$ \\
\hline VIT & & & $\begin{array}{c}0.069 \\
(0.068)\end{array}$ & $\begin{array}{c}0.105 \\
(0.080)\end{array}$ & & & $\begin{array}{c}0.144^{* *} \\
(0.062)\end{array}$ & $\begin{array}{c}0.094 \\
(0.071)\end{array}$ \\
\hline GDT & & & $\begin{array}{c}-0.091 \\
(0.074)\end{array}$ & $\begin{array}{c}0.016 \\
(0.083)\end{array}$ & & & $\begin{array}{c}-0.153^{* *} \\
(0.076)\end{array}$ & $\begin{array}{c}-0.188^{* *} \\
(0.083)\end{array}$ \\
\hline VDT & & & $\begin{array}{c}-0.105 \\
(0.073)\end{array}$ & $\begin{array}{c}-0.130^{*} \\
(0.070)\end{array}$ & & & $\begin{array}{c}-0.030 \\
(0.069)\end{array}$ & $\begin{array}{l}-0.035 \\
(0.075)\end{array}$ \\
\hline Agreeableness & & & $\begin{array}{c}0.004 \\
(0.014)\end{array}$ & $\begin{array}{c}-0.012 \\
(0.018)\end{array}$ & & & $\begin{array}{c}-0.006 \\
(0.012)\end{array}$ & $\begin{array}{l}-0.009 \\
(0.019)\end{array}$ \\
\hline Conscientiousness & & & $\begin{array}{c}0.022^{* *} \\
(0.010)\end{array}$ & $\begin{array}{c}0.015 \\
(0.014)\end{array}$ & & & $\begin{array}{l}0.019^{*} \\
(0.010)\end{array}$ & $\begin{array}{c}0.016 \\
(0.015)\end{array}$ \\
\hline Extroversion & & & $\begin{array}{c}-0.025^{*} \\
(0.013)\end{array}$ & $\begin{array}{c}-0.023^{*} \\
(0.013)\end{array}$ & & & $\begin{array}{c}0.012 \\
(0.014)\end{array}$ & $\begin{array}{c}0.019 \\
(0.016)\end{array}$ \\
\hline Emotional stability & & & $\begin{array}{c}0.012 \\
(0.013)\end{array}$ & $\begin{array}{c}0.010 \\
(0.017)\end{array}$ & & & $\begin{array}{c}0.002 \\
(0.014)\end{array}$ & $\begin{array}{c}0.003 \\
(0.018)\end{array}$ \\
\hline Openness & $\begin{array}{c}0.013 \\
(0.016)\end{array}$ & $\begin{array}{c}0.034^{* *} \\
(0.017)\end{array}$ & $\begin{array}{c}0.043^{* *} \\
(0.020)\end{array}$ & $\begin{array}{c}0.018 \\
(0.021)\end{array}$ & $\begin{array}{c}0.014 \\
(0.017)\end{array}$ & $\begin{array}{c}0.025 \\
(0.016)\end{array}$ & $\begin{array}{c}0.015 \\
(0.015)\end{array}$ & $\begin{array}{c}0.015 \\
(0.016)\end{array}$ \\
\hline Incons. & $\begin{array}{l}-0.399 \\
(0.257)\end{array}$ & $\begin{array}{l}-0.443^{*} \\
(0.254)\end{array}$ & $\begin{array}{l}-0.317 \\
(0.250)\end{array}$ & $\begin{array}{c}-0.554^{*} \\
(0.297)\end{array}$ & $\begin{array}{l}-0.299 \\
(0.282)\end{array}$ & $\begin{array}{l}-0.161 \\
(0.242)\end{array}$ & $\begin{array}{l}-0.015 \\
(0.224)\end{array}$ & $\begin{array}{l}-0.044 \\
(0.290)\end{array}$ \\
\hline Father edu. & & & & $\begin{array}{c}0.176 \\
(0.289)\end{array}$ & & & & $\begin{array}{c}0.073 \\
(0.330)\end{array}$ \\
\hline Mother edu. & & & & $\begin{array}{l}-0.070 \\
(0.295)\end{array}$ & & & & $\begin{array}{l}-0.202 \\
(0.343)\end{array}$ \\
\hline Constant & $\begin{array}{l}-1.338 \\
(2.636)\end{array}$ & $\begin{array}{l}-1.512 \\
(2.456)\end{array}$ & $\begin{array}{l}-2.498 \\
(2.904)\end{array}$ & $\begin{array}{c}0.213 \\
(3.155)\end{array}$ & $\begin{array}{l}-2.202 \\
(2.758)\end{array}$ & $\begin{array}{l}-3.250 \\
(2.806)\end{array}$ & $\begin{array}{c}-4.820^{*} \\
(2.663)\end{array}$ & $\begin{array}{l}-3.835 \\
(2.778)\end{array}$ \\
\hline Class FE & No & Yes & Yes & Yes & No & Yes & Yes & Yes \\
\hline Teachers' Gender & No & No & No & Yes & No & No & No & Yes \\
\hline Observations & 74 & 74 & 74 & 56 & 72 & 72 & 72 & 54 \\
\hline Adjusted R-squared & 0.0574 & 0.188 & 0.305 & 0.271 & 0.0185 & 0.194 & 0.218 & 0.255 \\
\hline
\end{tabular}

Robust standard errors in parentheses $* * * \mathrm{p}<0.01,{ }^{* *} \mathrm{p}<0.05,{ }^{*} \mathrm{p}<0.1$

Table 10: OLS regressions on IT and Physical Education scores (standardized) 